\title{
Molecular cloning and characterization of a novel aspartyl aminopeptidase from Trichinella spiralis
}

\author{
Sun, X.Y. ${ }^{1}$, Ma, K.N. ${ }^{1}$, Bai, Y. ${ }^{1}$, Liu, R.D. ${ }^{1}$, Long, S.R. ${ }^{1}$, Zhang, X. ${ }^{1}$, Jiang, ${ }^{1}{ }^{1}$, Cui,,${ }^{1 *}$, Wang, Z.Q. ${ }^{1 *}$ \\ ${ }^{1}$ Department of Parasitology, Medical College, Zhengzhou University, 40 Daxue Road, Zhengzhou 450052, People's Republic of China \\ *Corresponding author: wangzq@zzu.edu.cn, wangzq2015@126.com or Jing Cui; cuij@zzu.edu.cn
}

\section{ARTICLE HISTORY}

Received: 11 May 2021

Revised: 28 July 2021

Accepted: 29 July 2021

Published: 30 September 2021

\begin{abstract}
Trichinellosis is an important zoonotic parasitic disease worldwide and is principally caused by ingesting animal meat containing Trichinella infective larvae. Aspartyl aminopeptidase is an intracytoplasmic metalloproteinase that specifically hydrolyzes the $\mathrm{N}$-terminus of polypeptides free of acidic amino acids (aspartic acid and glutamate), and plays an important role in the metabolism, growth and development of organisms. In this study, a novel $T$. spiralis aspartyl aminopeptidase (TSAAP) was cloned and expressed, and its biological properties and roles in worm growth and development were investigated. The results revealed that TsAAP transcription and expression in diverse $T$. spiralis stages were detected by RT-PCR and Western blotting, and primarily localized at cuticle, stichosome and intrauterine embryos of this nematode by immunofluorescence test. rTsAAP has the enzymatic activity of native AAP to hydrolyze the substrate H-Glu-pNA. There was a specific binding between rTsAAP and murine erythrocyte, and the binding site was localized in erythrocyte membrane proteins. Silencing of TsAAP gene by specific dsRNA significantly reduced the TsAAP expression, enzymatic activity, intestinal worm burdens and female fecundity. The results demonstrated that TsAAP participates in the growth, development and fecundity of $T$. spiralis and it might be a potential target molecule for anti-Trichinella vaccines.
\end{abstract}

Keywords: Trichinella spiralis; aspartyl aminopeptidase; enzyme activity; RNA interference.

\section{INTRODUCTION}

Trichinella infects humans and more than 150 other mammals (such as pigs, horses, reptiles) and birds (Pozio, 2005). Trichinellosis is a food-borne zoonotic parasitic disease mainly resulted from ingestion of undercooked meat containing Trichinella larvae (Cui et al., 2011). The pork of domestic pigs is the principal infectious source of human trichinellosis in most developing countries (Cui et al., 2013a; Jiang et al., 2016; Rostami, 2017). But it is hard to interdict Trichinella infection in animals because of its broad distribution of animal hosts (Liu et al., 2015b). Anti-Trichinella vaccines need to be developed for blocking and eliminating Trichinella infection in food animals (Bai et al., 2017). The current development of anti-Trichinella vaccines is mainly focused on identification of new protective antigens and combined vaccination. Vaccination with an individual recombinant Trichinella protein only induced about $50 \%$ immune protection against Trichinella challenge infection (Yue et al., 2020). Vaccination of mice with two recombinant Trichinella proteins or protein combined with DNA vaccine conferred a more significant reduction of larval burden than a single protein or DNA vaccine (Zhang et al., 2018; Xu et al., 2020a). Hence, it is requisite to characterize novel Trichinella proteins as the candidate target molecules of preventive vaccines against Trichinella infection (Ren et al., 2019, 2021).

After being ingested, the $T$. spiralis muscle larvae (ML) contained in infected meat are released under the action of the host's gastric juice and activated to intestinal infective larvae (IIL), the IIL intrude into intestinal mucosal epithelium where they develop into adult worms (AW). After mating, the female worms produce newborn larvae (NBL) that migrate throughout the host's body and invade the skeletal muscles to become the encapsulated ML (Campbell, 1983; Ren et al., 2011). Muscle larvae survive in the host for several years until it is ingested by a new host, thus starting a new round of life cycle (Li et al., 2015). However, the mechanism of survival and immune escape of this parasitic nematode is not completely elucidated.

Peptidases are divided into three categories according to their substrates, namely aminopeptidase, carboxypeptidase and endopeptidase. Aminopeptidase hydrolyzes the amino acid at the amino end of the peptide chain (Walling, 2006). Aspartyl aminopeptidase (AAP) is assigned to the M18 family of peptidases, widely distributed in bacteria and eukaryotes, and is a highly conserved cytoplasmic enzyme. AAP is an intracytoplasmic metalloproteinase that specifically hydrolyzes the $\mathrm{N}$-terminus of polypeptides free of acidic amino acids 
(aspartic acid and glutamate). The AAP has strong selectivity for N-terminal aspartic acid and glutamic acid residues (Wilk et al., 1998). Current research on parasite AAP is mainly focused on protozoa. Previous studies have found that Toxoplasma gondii AAP (TgAAP) in the cytosol was essential for its blood stage replication, TgAAP gene knockout inhibited the $T$. gondii invasion and growth, and this enzyme may be a promising candidate target for anti-Toxoplasma drugs (Zheng et al., 2016). Plasmodium falciparum AAP (PfM18AAP) performs various functions in host red blood cells, such as hemoglobin digestion, red blood cell invasion, parasite growth and parasite escape from host cells (Kumari et al., 2016). P. falciparum requires a variety of metal aminopeptidases. PfM1MAA (membrane alanine aminopeptidase), PfM17LAP (leucine aminopeptidase) and PfM18AAP (aspartyl aminopeptidase) synergistically degrade host hemoglobin to generate free amino acids, which can be used as a source of amino acids to synthesize their own proteins. Plasmodium mutated Cin the M18AAP enzyme cannot survive, indicating that it plays a key role in the survival of $P$. falciparum and can serve as an important molecular target for development of potential therapeutic agents for the control of malaria infections (Lauterbach \& Coetzer, 2008). P. vivax AAP is a single gene copy present in Plasmodium, the AAP acts in the final stage of host hemoglobin and completes the hydrolysis process (Rout \& Mahapatra, 2019).

In previous studies, a T. spiralis aminopeptidase (TsAP) has been identified in proteases generated by the IIL larvae after co-culture with intestinal epithelial cells (IEC). Moreover, TsAP was also identified in AW excretion/secretion (ES) protein (Wang et al., 2013c, 2017). TsAP participates in T. spiralis invasion, development and fecundity (Guo et al., 2020). But TsAP did not include $T$. spiralis AAP (TsAPP), the TsAPP was not identified and characterized before.

In the present study, a novel $T$. spiralis TsAAP (TsAAP, GenBank: KRY29491.1) is retrieved from the draft genome of this parasite (Mitreva et al., 2011), but its biological functions in $T$. spiralis lifecycle was not reported in the literatures. The aim of this study was to investigate the biological properties and roles of TsAAP in growth and development of $T$. spiralis.

\section{MATERIALS AND METHODS}

\section{Parasites, animals and antigens}

Trichinella spiralis isolate (ISS534) was acquired from domestic pigs naturally infected in central China (Wang et al., 2012). The 4-6 week old female Kunming mice was purchased from Henan Experimental Animal Center (Zhengzhou, China). The $\mathrm{ML}$ was collected from infected murine carcasses at 40 days post infection (dpi) by artificial digestion method (Jiang et al., 2012). The IIL at 6 hours post infection (hpi), and AW at 3 and 6 days post infection (dpi) were recovered from infected murine small intestine (Liu et al., 2015d; Sun et al., 2015). Adult females at $6 \mathrm{dpi}$ were cultured in RPMI-1640 with $10 \%$ fetal bovine serum (FBS; Gibco) at $37^{\circ} \mathrm{C}, 5 \% \mathrm{CO}_{2}$ for $24 \mathrm{~h}$, and NBL were collected (Zhang et al., 2013; Wu et al., 2016). The somatic crude proteins and ES proteins of various $T$. spiralis stage worms (ML, IIL, $3 \mathrm{~d}$ AW, $6 \mathrm{~d}$ AW and NBL) were prepared as previously reported (Yang et al., 2015).

\section{Bioinformatics analysis of TsAAP}

The structural domain and enzyme active sites of TsAAP (GenBank: KRY29491.1) were predicted and analyzed by using online webtool and CN3D software (Song et al., 2018b). The amino acid sequence of TsAAP gene was compared with AAP from different species /genotypes of Trichinella by using Clustal X (Zhang et al., 2020b). The GenBank accession numbers of AAP from Trichinella spp. and other organisms were as follows: T. spiralis (KRY29491.1), T. nelsoni (KRX25887.1), T. britovi (KRY46829.1), T9 (KRX51999.1), T6 (KRX76744.1), T. nativa (KRZ55718.1), T. murrelli (KRX35979.1), T. patagoniensis (KRY14399.1), T8 (KRZ82592.1), T. papuae (KRZ70603.1), T. zimbabwebsis (KRZ06548.1), T. pseudospiralis (KRX94200.1), Homo sapiens (NP_001306047.1) and Mus musculus (AAD01212.1). At present, based on the presence or absence of a collagen capsule that surrounds the ML in the muscle cell (i.e., nurse cell), the genus Trichinella is classified into two major clades. Members of the encapsulated clade, which infect only mammals, are $T$. spiralis, $T$. nativa, T. britovi, T. murrelli, T. nelsoni, T. patagoniensis, and three other genotypes Trichinella T6, T8 and T9. The other non-encapsulated clade, which infects mammals, reptiles and/or birds, consists of T. pseudospiralis, T. papuae and T. zimbabwensis (Zarlenga et al., 2020). The phylogenetic analysis was performed in MEGA 7.0 based on the Neighbor-joining (NJ) method as described previously (Zhang et al., 2013; Qi et al., 2018b).

\section{Cloning, expression and identification of TsAAP}

Total RNA was isolated from the ML using Trizol (Invitrogen, USA). The full-length cDNA sequence of TsAAP was amplified by $P C R$ using specific primers with restriction enzyme sites BamH I and Pst I (underlined) (5'-AGCCGGATCCATGAATGGAAAAT GTTGTTC-3'; 5'-CGGCTGCAGTTATAATTTTTTGTCGACTTCGG-3'). The PCR products were cloned into the expression vector $\mathrm{PQE}-$ $80 \mathrm{~L}$, then the recombinant $\mathrm{pQE}-80 \mathrm{~L} / \mathrm{Ts} A \mathrm{AP}$ was transformed into Escherichia coli BL21 (DE3) (Novagen, USA). The rTsAAP was expressed by the induction using $1 \mathrm{mM}$ IPTG for $8 \mathrm{~h}$ at $30^{\circ} \mathrm{C}$ (Xu et al., 2018, 2020b), subsequently purified using $\mathrm{Ni}-$ NTA-Sefinose resin (Sangon Biotech Co, Shanghai, China) (Liu et al., 2017). The concentrations of the purified rTsAAP proteins were measured by Bradford method, and separated and identified on SDS-PAGE and Western blotting (Wang et al., 2017).

Murine immunization and polyclonal anti-rTsAAP antibody assay Twenty mice were subcutaneously immunized with $20 \mu \mathrm{g}$ rTsAAP emulsified with complete Freund's adjuvant. Three boosts were performed with $20 \mu \mathrm{g}$ rTsAAP emulsified by incomplete Freund's adjuvant at a 2-week-interval (Sun et al., 2018b; Hu et al., 2020a). One week after the last immunization, tail blood was collected and anti-rTsAAP serum was separated (Cui et al., 2013b). Serum anti-rTsAAP antibody IgG in serum samples of immunized mice was assayed by using ELISA (Xu et al., 2021b). Briefly, the ELISA plate was coated with $2.5 \mu \mathrm{g} / \mathrm{ml}$ rTsAAP at $4^{\circ} \mathrm{C}$ overnight. After washes using phosphate buffered saline $(\mathrm{pH} 7.4)$ containing $0.05 \%$ Tween-20 (PBST), the plate was blocked with $5 \%$ skimmed milk at $37^{\circ} \mathrm{C}$ for $2 \mathrm{~h}$, probed with $1: 100$ dilutions of murine immune sera at $37^{\circ} \mathrm{C}$ for $2 \mathrm{~h}$, followed by the incubation of HRP-conjugated anti-mouse IgG (1:10000; Sigma) for $1 \mathrm{~h}$ at $37^{\circ} \mathrm{C}$. Plates were developed with OPD (Sigma; USA) plus $\mathrm{H}_{2} \mathrm{O}_{2}$, the reaction was finished by addition of $2 \mathrm{M} \mathrm{H}_{2} \mathrm{SO}_{4}$. The OD values at $492 \mathrm{~nm}$ were assayed by a microplate reader (Tecan, Schweiz, Switzerland) (Liu et al., 2015a; Lei et al., 2020).

\section{Western blotting and RT-PCR}

Western blotting analysis was conducted as previously reported (Liu et al., 2016; Yang et al., 2020a). Somatic crude proteins from various $T$. spiralis stage worms and rTsAAP were separated by SDS-PAGE and transferred onto PVDF membranes (Merck Millipore, USA) at $18 \mathrm{~V} 35 \mathrm{~min}$. The membranes were blocked with $5 \%$ skimmed milk in TBST. The membrane was cut into strips which were probed with 1:100 dilutions of anti-TsAAP serum at $37^{\circ} \mathrm{C}$ for $2 \mathrm{~h}$. After 
washes using Tris buffered saline (pH 7.4) containing $0.05 \%$ Tween-20 (TBST), the membranes were further incubated with HRP-conjugated goat anti-mouse IgG (1:10 000; Southern Biotech). Finally, the membranes were developed with $D A B$ (Sigma), and the coloration was stopped with deionized water.

RT-PCR analysis of TsAAP transcription was performed as described before (Wang et al., 2013a; Xu et al., 2021a). Total RNAs from diverse $T$. spiralis stages (ML, IIL, AW and NBL) was extracted with TRIzol reagent (Invitrogen). T. spiralis GAPDH (GenBank: AF452239) was also amplified and used as a housekeeping gene control (Long et al., 2015). PBS was used as a negative control in all PCRs.

\section{Indirect immunofluorescence (IIF)}

The IIF test was carried out with fresh complete worms of diverse $T$. spiralis phases (ML, IIL, AW and NBL) as reported before (Li et al., 2018; Liu et al., 2018). The intact worms were fixed with $4 \%$ formaldehyde for $30 \mathrm{~min}$, and then re-fixed with cold acetone for $20 \mathrm{~min}$. Moreover, worms were embedded in paraffin and cut into $2 \mu \mathrm{m}$ thick cross-sections with a microtome. The intact whole nematodes and crosssections were blocked with $5 \%$ normal goat serum in PBS, and then probed at $37^{\circ} \mathrm{C}$ for $1 \mathrm{~h}$ with a 1:10 dilution of various sera (anti-rTsAAP serum, infection serum or pre-immune serum). After washing with PBS, they were incubated with FITC-conjugated goat anti-mouse IgG (1:100; Santa Cruz, USA). After washing again, the whole worms and cross-sections were observed under a fluorescence microscopy (Olympus, Japan) (Cui et al., 2019; Zhang et al., 2020a).

\section{Enzymatic activity assay of rTsAAP}

To determine the enzymatic activity of $\mathrm{rTsAAP}$, the diluted rTsAAP $(0,0.01,0.02,0.03,0.04,0.05,0.06,0.07 \mu \mathrm{g} / \mu \mathrm{l})$ was preincubated at $37^{\circ} \mathrm{C}$ for $10 \mathrm{~min}$ in various $\mathrm{pH}$ buffer $(0.05 \mathrm{M}$ Tris$\mathrm{HCl}$ buffer is used at $\mathrm{pH} 7.0-9.0$, and $0.1 \mathrm{~mol} / \mathrm{L}$ citric acidsodium citrate buffer is used at $\mathrm{pH} 6.0$ and 6.5 ), subsequently the AAP substrate $0.1 \mathrm{mM} \mathrm{H}$-Glu-P-nitroaniline (H-Glu-pNA, Yuanye, Shanghai, China) was added into the reaction mixture and incubated at different temperatures $\left(17-47^{\circ} \mathrm{C}\right)$ for $30 \mathrm{~min}$, and the absorbance at $410 \mathrm{~nm}$ was measured with a spectrophotometer (Lauterbach \& Coetzer, 2008). In order to verify whether the enzymatic activity of rTsAAP depends on metal ions, the common auxiliary metal ions $\left(\mathrm{Mg}^{2+}, \mathrm{Ca}^{2+}, \mathrm{Zn}^{2+}, \mathrm{Cu}^{2+}\right.$, $\mathrm{Mn}^{2+}, \mathrm{Co}^{2+}, \mathrm{Ni}^{2+}, \mathrm{Fe}^{2+}$ ) were added into the reaction system at the same concentration $(0.1 \mathrm{mM})$ to analyze their effect on enzyme activity (Park et al., 2017; Guo et al., 2020). Effects of different enzyme inhibitors ( $1 \mathrm{mM}$ PMSF, $5 \mu \mathrm{M}$ E64, $10 \mathrm{mM}$ EDTA and $1 \mathrm{mM}$ AEBSF) on rTsAAP activity were also determined (Cui et al., 2015a). Standard curve was calculated according to rTsAAP hydrolysis of different concentrations of substrate H-Glu-pNA (0.1, 0.2, 0.3, 0.4, 0.5, 0.6, 0.7, $0.8 \mathrm{mM})$, and obtained $\mathrm{Km}$ on the basis of Michaelis-Menten curve and LineweaverBurk curve value (Long et al., 2015).

\section{IIF assessment of binding of rTsAAP and erythrocytes}

Normal murine blood samples were first diluted with isosmotic PBS buffer (pH 7.4). Blood smear was prepared on slides, fixed with formaldehyde for $15 \mathrm{~min}$, then washed with PBS, and blocked with $5 \%$ goat serum at $37^{\circ} \mathrm{C}$ for $2 \mathrm{~h}$. After washing with $\mathrm{PBS}$, the slides were incubated at $37^{\circ} \mathrm{C}$ for $2 \mathrm{~h}$ with different proteins ( $\mathrm{rTsAAP}$, AW crude proteins, maltose binding protein (MBP), and rTsAAP treated by EDTA). The slides were probed with different sera (1:10; anti-rTsAAP serum, anti-MBP serum, infection serum, and normal serum) at $37^{\circ} \mathrm{C}$ for $2 \mathrm{~h}$. After washing, FITC-conjugated anti-mouse IgG (1:100, Santa Cruz) was incubated at $37^{\circ} \mathrm{C}$ for $1 \mathrm{~h}$, and examined under fluorescence microscopy (Cui et al., 2015b; Yan et al., 2021).

\section{Binding of rTsAAP and erythrocyte membrane proteins determined} by Far Western

The in vitro binding between rTsAAP and erythrocyte membrane proteins was analyzed by Far-western analysis (Hu et al., 2020b). Erythrocytes were hemolysed, centrifuged at of $15000 \mathrm{~g}$ for $10 \mathrm{~min}$. Supernatant was discarded, sediment was supplemented with $5 \mathrm{mmol} \cdot \mathrm{L}^{-1}$ Tris- $\mathrm{HCl}(\mathrm{pH} 7.4)$ and centrifuged again to obtain erythrocyte membrane (Coetzer and Palek, 1986). Erythrocyte membrane was boiled and membrane proteins were separated by SDS-PAGE with $12 \%$ separation gel (Wang et al., 2013b). After being blotted, the membrane cut into strips, blocked using 5\% skimmed milk in TBST at $37^{\circ} \mathrm{C}$ for $2 \mathrm{~h}$, and incubated with rTsAAP for $2 \mathrm{~h}$ at $37^{\circ} \mathrm{C}$. The strips were probed anti-rTsAAP serum, anti-mouse IgG-HRP conjugate (1:10 000; Southern Biotech), and developed using substrate DAB (sigma) (Han et al., 2020).

\section{RNA interference}

TsAAP-specific dsRNA target sequence of $555^{\sim 1176} \mathrm{bp}$ of full length TsAAP cDNA sequence was selected to design the primers (Table 1). To verified the specificity of TsAAP-dsRNA, a T. spiralis cathepsin L gene (TsCL, GenBank: XM_003375022.1) was used as a specific control. Besides, green fluorescent protein (GFP) dsRNA was prepared for a negative control. The $5^{\prime}$ end of the upstream and downstream PCR primer to amplify TsAAP gene was added with the T7 promoter sequence (Zhang et al., 2016). dsRNA was introduced into $T$. spiralis larvae by electroporation and cultured in RPMI 1640 medium at $37^{\circ} \mathrm{C}$ for 3 days. $\mathrm{qPCR}$ and Western blot analysis was performed to determine the expression level of TsAAP in ML (Liu et al., 2013; Han et al., 2020), and the expression level of GAPDH protein was used as a housekeeping gene control (Yang et al., 2019). The enzyme activity of natural TsAAP in crude proteins of dsRNA-TsAAP treated ML was analyzed by the above-described method and compared with the untreated ML.

Table 1. TsAAP-specific primers flanked by T7 RNA polymerase promoter sequences

\begin{tabular}{ll}
\hline Primer & \multicolumn{1}{c}{ Sequences } \\
\hline T7-F-TsAAP & 5'-GATCACTAATACGACTCACTATAGGGCACGTTCACCTCCAATACGAC-3' \\
T7-R-TsAAP & 5' -GATCACTAATACGACTCACTATAGGGTGTAGATCCGCATCCGATGTC-3' \\
T7-F-GFP & 5'-GATCACIAATACGACTCACTATAGGGAGTGCTTCAGCCGCTACC-3' \\
T7-R-GFP & 5'-GATCACTAATACGACTCACTATAGGGGCTTCTCGTTGGGGTCTT-3' \\
\hline
\end{tabular}

The underlined portion is T7 promoter sequence. 


\section{Challenge infection of mice with dsRNA-TsAAP transfected $T$. spiralis larvae}

In order to investigate the larval development in host intestine after dsRNA-TsAAP interference, 30 mice were equally divided into 3 groups for larval challenge experiment. Each mouse was infected orally with $500 \mathrm{ML}$ treated with 60 $\mathrm{ng} / \mu \mathrm{l}$ dsRNA-TsAAP, Control dsRNA or PBS. At 3 and $6 \mathrm{dpi}$, intestinal adult worms were collected from 5 mice of each group, and intestinal worm burdens were ascertained and adult morphology were observed under microscopy (Liu et al., 2015c). Fifty female adult worms at 6 dpi from each group of infected mice were cultivated, and female reproduction capacity (fecundity) was assessed according to the production of NBL deposited by each female within 72 h (Qi et al., 2018a; Sun et al., 2019).

\section{Statistical analysis}

All data were analyzed using SPSS 21.0 software, and the data were expressed as mean \pm standard deviation (SD). Chi-square test was used to analyze the relative transcription and expression levels of TsAAP among various groups, and One-way ANOVA was used to analyze the differences of adult burdens, NBL production and parasite length. $P<0.05$ is considered statistically significant.

\section{RESULTS}

\section{Bioinformatics analysis of TsAAP}

The full-length cDNA sequence of TsAAP gene is $1404 \mathrm{bp}$ encoding 467 amino acids, with a molecular weight (MW) of $51.76 \mathrm{kDa}$ and isoelectric point (pl) of 6.24. TsAAP had no signal peptide site. The homology of TsAAP amino acid sequences was compared with AAP of other species or genotypes of the genus Trichinella. The amino acid sequences of the TSAAP had an identity of $94-99 \%$ with AAP of the 8 encapsulated Trichinella species, and an identity of 91-92\% with AAP of three non-encapsulated Trichinella species.

SMART analysis showed that TsAAP contained a Peptidase_M18 domain, which has the function of catalysis of the hydrolysis of $\mathrm{N}$-terminal amino acid residues. In the three-dimensional model, TsAAP has fourteen enzymatic activity sites ( 3 histidines, 2 glutamic acids, 2 aspartic acids, asparagine, serine, glycine, tyrosine, lysine, valine, methionine). Phylogenetic analysis results of TsAAP with AAP from Trichinella spp. showed that the monophyletic groups of 11 species/genotypes of Trichinella are well supported, and there are two distinct clades, one was the encapsulated clade (including $T$. spiralis, $T$. nelsoni, T6, T. nativa, $T$. patagoniensis, T. murrelli, T. britovi, T9 and T8), the other was the non-encapsulated clade (T. pseudospiralis, T. zimbabwensis and $T$. papuae). Compared with other Trichinella species/ genotypes, TsAAP is closely related to $T$. nelsoni.

\section{Western blotting identification of rTsAAP antigenicity \\ The results of SDS-PAGE analysis showed that pQE-80L/TsAAP BL21 expressed a $51.76 \mathrm{kDa}$ protein band. After purification with Ni-NTA Sefinose Column, a clear rTsAAP band with 51.76 $\mathrm{kDa}$ was observed, and the rTsAAP MW was consistent with its predicted size $(51.76 \mathrm{kDa})$. Western blot analysis showed that lysates of recombinant pQE-80L/TsAAP prior to induction were not detected by infection serum. rTsAAP was recognized by anti-rTsAAP immune serum and anti-his tag monoclonal antibody (McAb), but not by pre-immune serum (Figure 1).}

\section{Transcription and expression of TsAAP in different worm stages} The RT-PCR results showed that TSAAP gene was transcribed in different $T$. spiralis phase worm (ML, IIL, 3 and $6 \mathrm{~d} \mathrm{AW}$, and $\mathrm{NBL}$ ), and the GAPDH internal control gene also produced

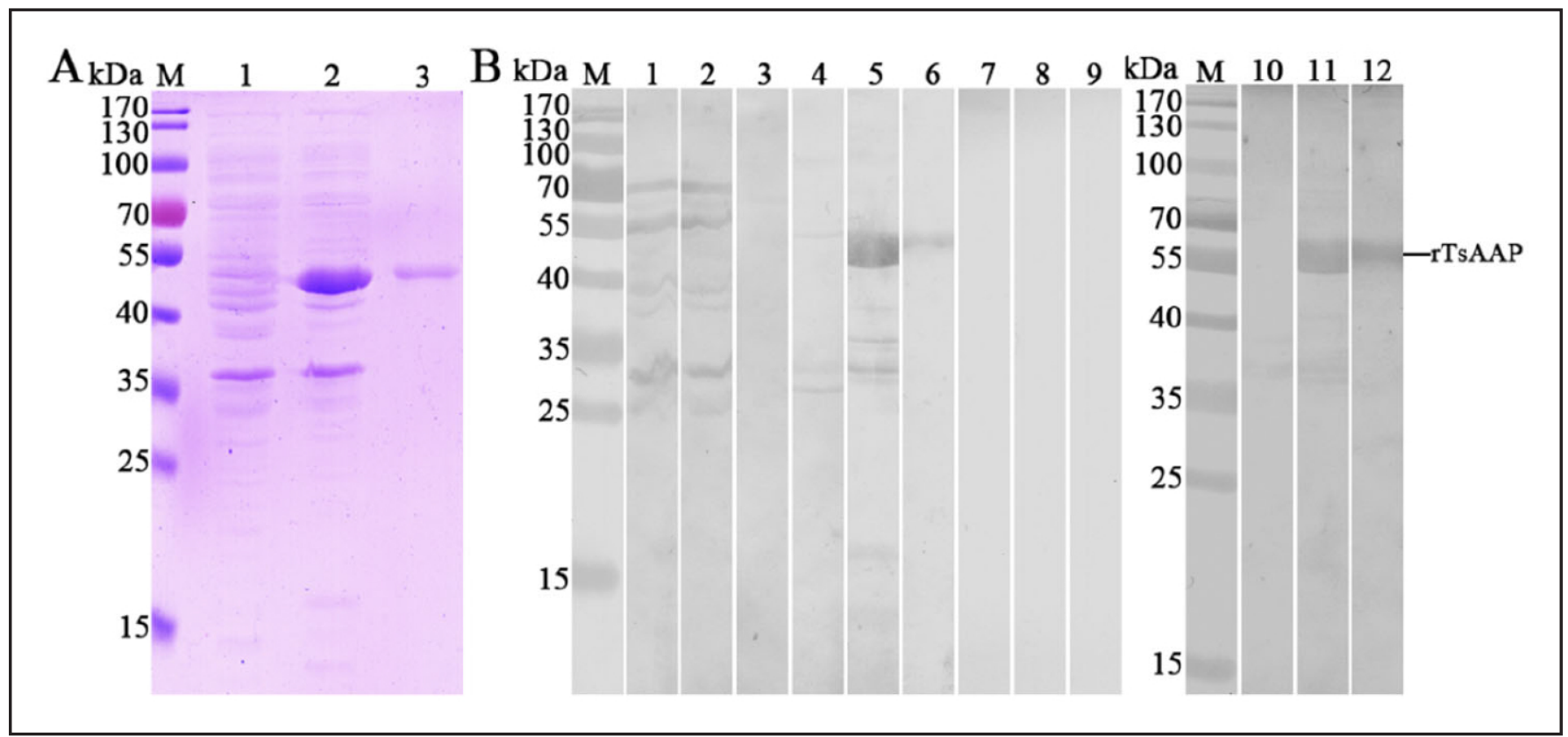

Figure 1. Antigenicity of rTsAAP protein. A: SDS-PAGE analysis of rTsAAP. Lane M: Protein marker; lane 1: lysate of recombinant $E$. coli incorporating pQE-80L/TsAAP prior to induction; lane 2: lysate of recombinant $E$. coli carrying pQE-80L/TsAAP following induction; Lane 3: purified rTsAAP. B: Western blotting of rTsAAP. Lysates of pQE-80L/TsAAP prior to induction (Lane 1, 4, 7 and 10) were not detected by infection serum (lane 1), anti-rTsAAP serum (Lane 4), pre-immune serum (Lane 7) and anti-his McAb (Lane 10). The lysates of pQE-80L/TsAAP following induction (Lane 2, 5, 8 and 11) and purified rTsAAP (Lane 3, 6, 9 and 12) were probed by antirTsAAP serum (Lane 5 and 6) and anti-his McAb (Lane 11and 12), but not by T. spiralis infected serum (lane 2 and 3 ) and preimmune serum (Lane 8 and 9). 
the expected size (570 bp) in all developmental phases (Figure 2). The natural TsAAP with $51.76 \mathrm{kDa}$ in worm crude proteins of various phases (ML, IIL, 3 and $6 \mathrm{~d}$ AW and NBL) was identified by anti-rTsAAP serum on Western blotting analysis.

Expression and worm tissue location of native TsAAP in diverse $T$. spiralis stage

The results of IIF with whole parasites revealed that green immunostaining on the epicuticle of IIL, AW and NBL other than $\mathrm{ML}$ was observed using anti-rTsAAP serum and infection serum (Figure 3 ). When worm cross-sections were probed by anti-rTsAAP serum, the green fluorescence was located at the cuticle and stichosome of $\mathrm{ML}$ and IIL, and intrauterine embryos of female adults (Figure 4). No worm tissue components of the nematode were identified by pre-immune serum.

\section{Enzyme activity of rTsAAP}

The enzyme activity of rTsAAP increased with elevation of rTsAAP protein concentration, and stabilized when the rTsAAP concentration was $0.06 \mu \mathrm{g} / \mu \mathrm{l}$ (Figure 5). rTsAAP enzyme activity is the highest at $37^{\circ} \mathrm{C}$ and $\mathrm{pH}$ 7.5. The metal ions $\mathrm{Co}^{2+}, \mathrm{Mn}^{2+}$, $\mathrm{Mg}^{2+}$, and $\mathrm{Ni}^{2+}$ enhanced the activity of rTsAAP enzyme, the effect size is $\mathrm{Co}^{2+}>\mathrm{Mn}^{2+}>\mathrm{Ni}^{2+}>\mathrm{Mg}^{2+}$, and $\mathrm{Ca}^{2+}, \mathrm{Zn}^{2+}, \mathrm{Cu}^{2+}, \mathrm{Fe}^{2+}$ have obvious inhibitory effect on rTsAAP enzyme activity. EDTA inhibited the rTsAAP enzymatic activity. The hydrolysis of $\mathrm{H}$ Glu-pNA by rTsAAP conformed to Miman's kinetics. The kinetic parameter Vmax is $194.9 \mu \mathrm{M} \cdot \mathrm{min}^{-1} \cdot \mathrm{mg}^{-1}$, and the $\mathrm{Km}$ is 1.05 $\mathrm{mM}$.

\section{Binding of rTsAAP and erythrocyte by IIF}

The IIF results showed that when anti-rTsAAP serum was used, green fluorescence was observed on the surface of erythrocytes pre-incubated with rTsAAP, but no fluorescence staining was observed on surface of erythrocytes detected by normal serum and PBS (Figure 6). The erythrocytes preincubated by heat-inactivated rTsAAP and EDTA-treated rTsAAP did not exhibit any green fluorescence. The results showed that rTSAAP specifically combined to the surface of erythrocyte membrane.

Binding of rTsAAP and erythrocyte membrane proteins determined by Far Western

SDS-PAGE results showed that erythrocyte membrane proteins had 6 bands of 42-240 kDa. Far-western blotting revealed that five bands $(42,76,80,220$ and $240 \mathrm{kDa})$ of them pre-incubated with rTsAAP were recognized by anti-rTsAAP serum, but not by normal mouse serum (Figure 7). Four bands $(76,80,220$ and $240 \mathrm{kDa})$ of them pre-incubated with rTsAAP were also recognized by infection serum. One band (114.4 $\mathrm{kDa}$ ) pre-incubated with rTsAAP was not recognized by infection serum. Additionally, erythrocyte membrane proteins pre-incubated with MBP were not probed by anti-MBP serum. The results suggested that ITSAAP specifically was bound to erythrocyte membrane proteins (240 kDa $\alpha$-spectrin, $220 \mathrm{kDa}$ $\beta$-spectrin, $80 \mathrm{kDa}$ protein $4.1,76 \mathrm{kDa}$ protein 4.2 , and $42 \mathrm{kDa}$ actin).

Suppression of TsAAP expression and enzymatic activity by dsRNA-

\section{TsAAP}

dsRNA was introduced into the ML by electroporation and larval survival was observed after being cultured for $3 \mathrm{~d}$. The results showed that larval survival rates of dsRNA-TSAAP, dsRNA-GFP and PBS group were 99.46, 99.49 and $98.78 \%$, respectively $\left(\chi^{2}=0.276, P>0.05\right)$, suggesting that electroporation has no obvious effect on larval survival. When the ML were transfected with different dose of dsRNA-TsAAP of $(15,30,45,60 \mathrm{ng} / \mu \mathrm{l})$ and cultured for 3 days, compared with the PBS group, TsAAP mRNA expression levels were reduced

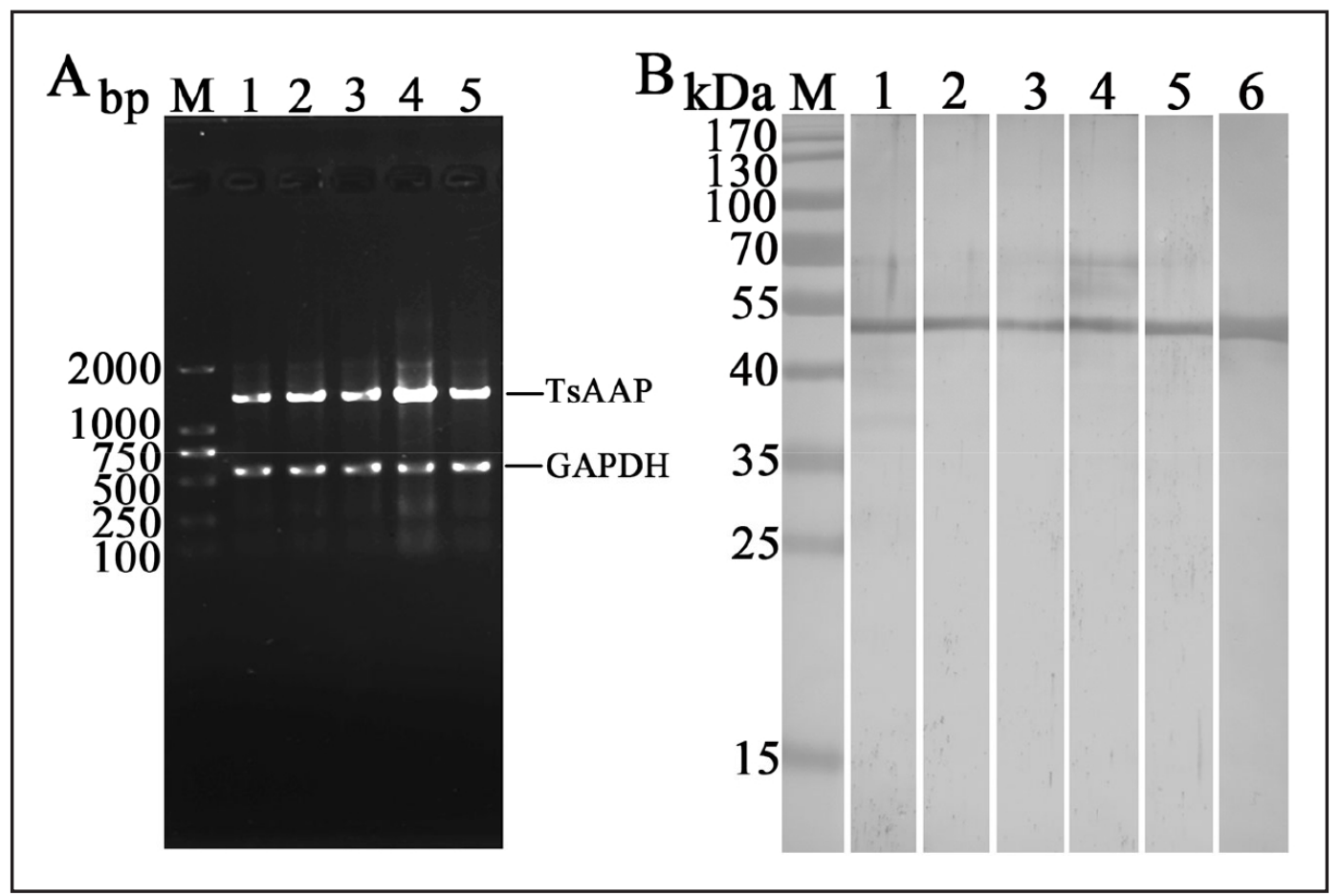

Figure 2. Transcription and expression of TsAAP in diverse $T$. spiralis stages. A. RT-PCR analysis of TsAAP gene transcription in different stages. M: DNA marker; 1: ML; 2: $6 \mathrm{~h}$ IIL; 3: $3 \mathrm{~d}$ AW; 4: $6 \mathrm{~d}$ AW; 5: NBL. B: Identification of native TSAAP in crude proteins of various $T$. spiralis stages on Western blot analysis with anti-rTsAAP serum. Lane 1: ML; lane 2: IIL; lane 3: $3 \mathrm{~d}$ AW; lane 4: $6 \mathrm{~d}$ AW; lane 5: NBL and rTsAAP (lane 6) probed by anti-rTsAAP serum was served as positive control; M: Protein marker. 


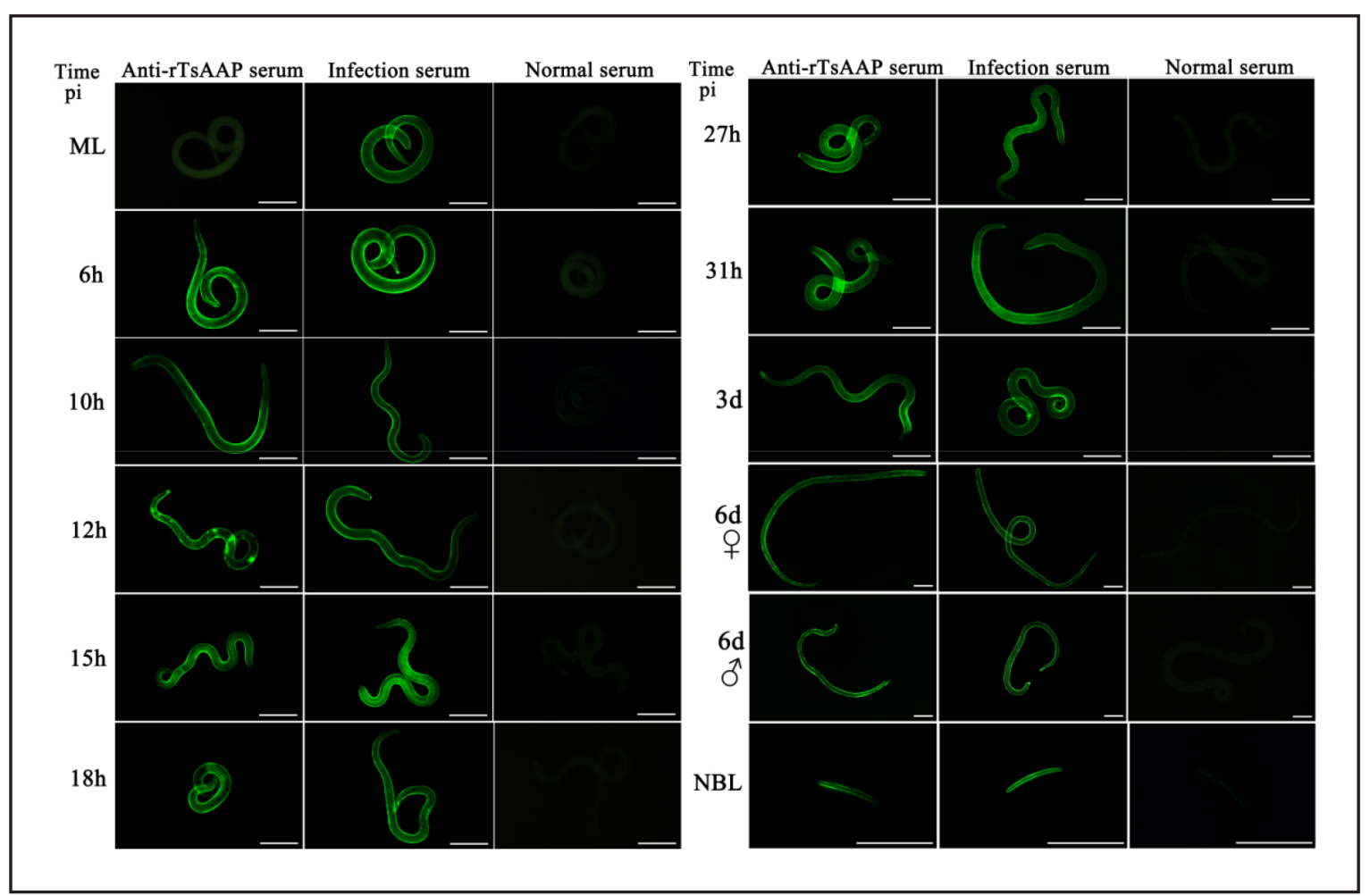

Figure 3. Expression of TsAAP at epicuticle of various $T$. spiralis stages by IIF. The whole worms were probed by anti-rTsAAP serum, and immunostaining was observed at the epicuticle of 6-31 h IIL, AW and NBL, but not at ML epicuticle. Normal serum did not recognize any worm components of the parasite. Scale bars of ML, IIL and $\mathrm{AW}=100 \mu \mathrm{m}$; Scale bars of $\mathrm{NBL}=50 \mu \mathrm{m}$.

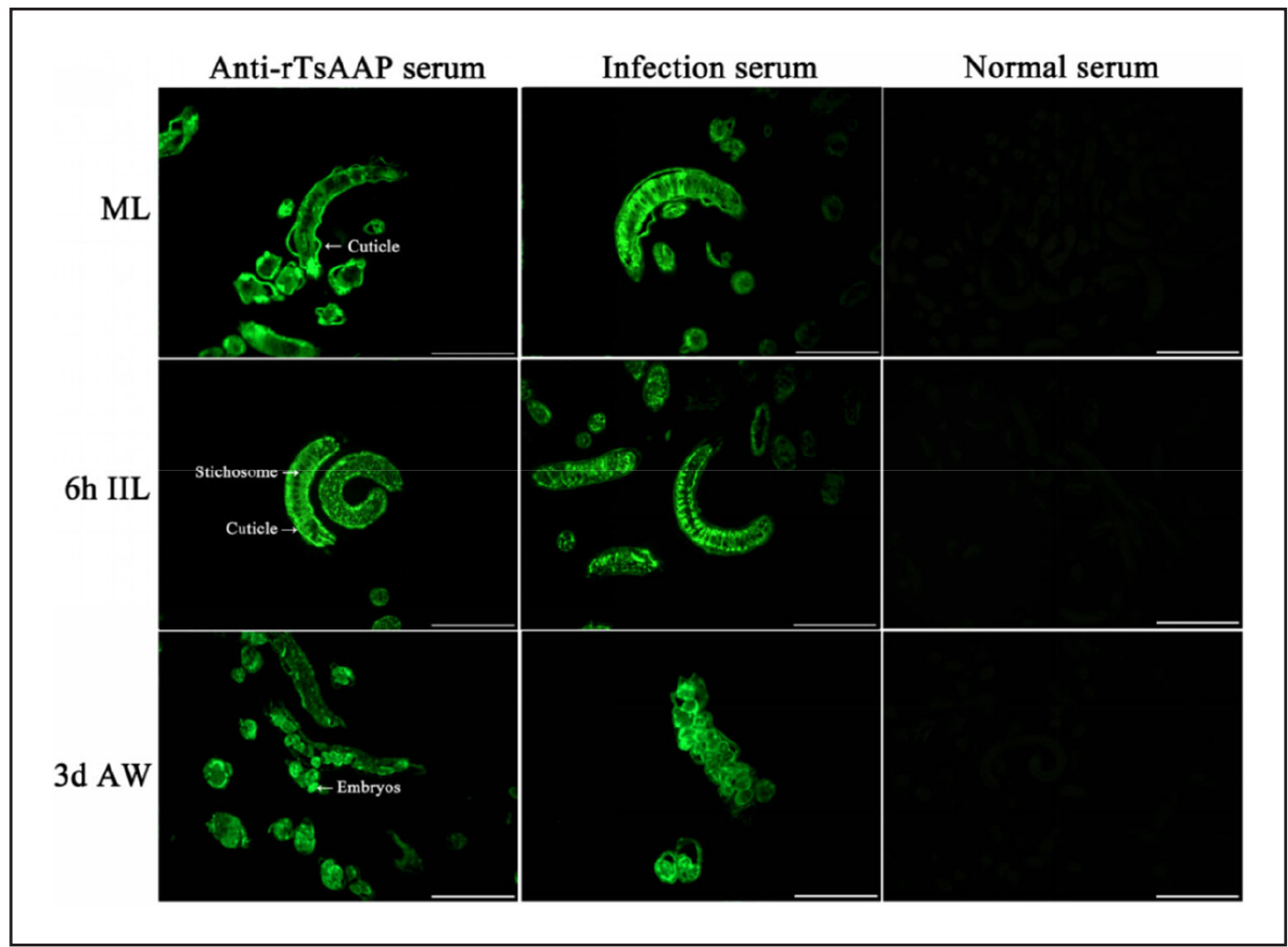

Figure 4. Immunolocalization of TSAAP in cross-sections of diverse $T$. spiralis stages by IIF with anti-rTsAAP serum. Fluorescence staining was observed at cuticle of ML, IIL and intrauterine embryos of adult females. No immunostaining in worm cross-sections was observed by using normal serum as a negative control. Scale bars: $100 \mu \mathrm{m}$. 

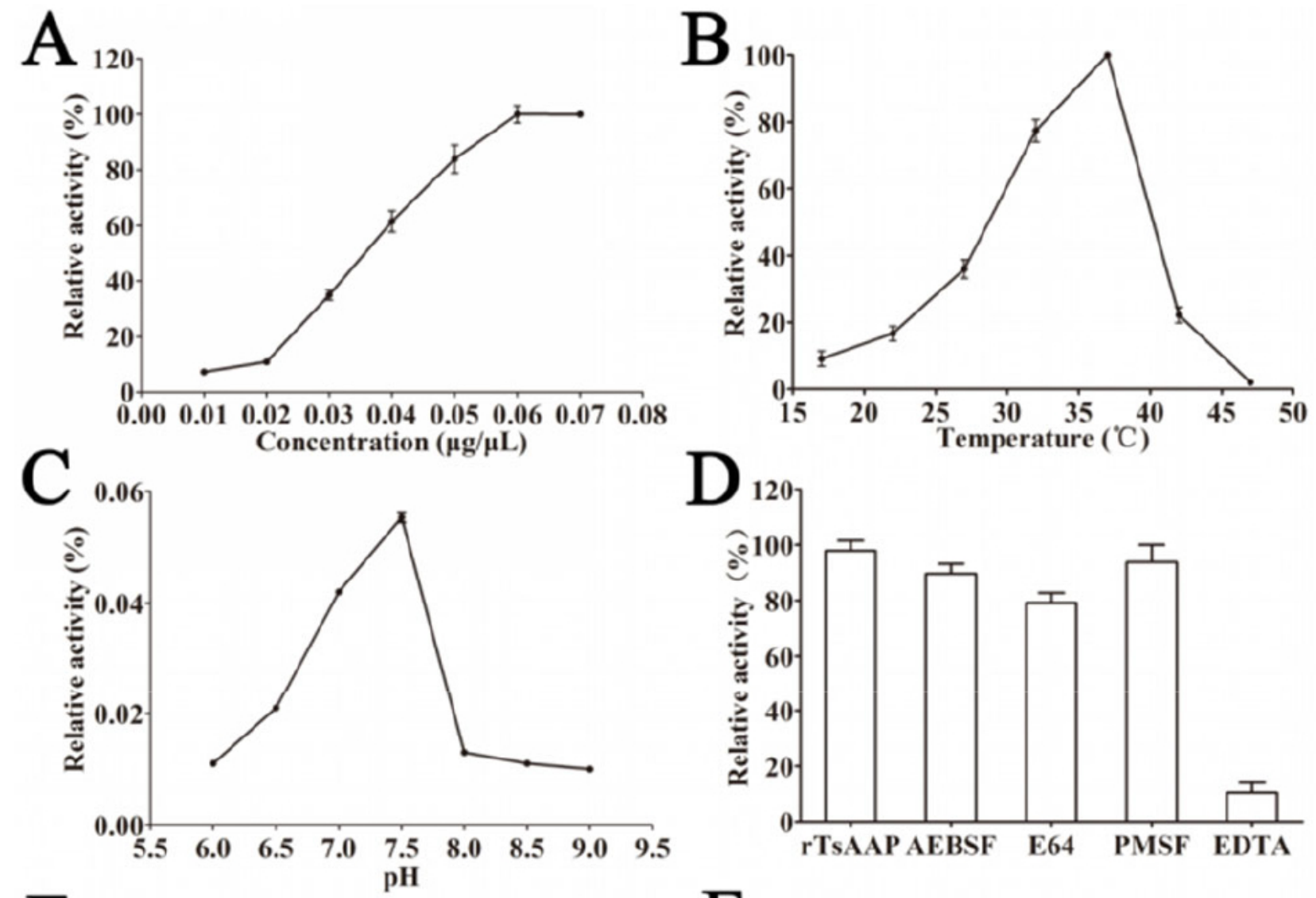

$\mathrm{D}$

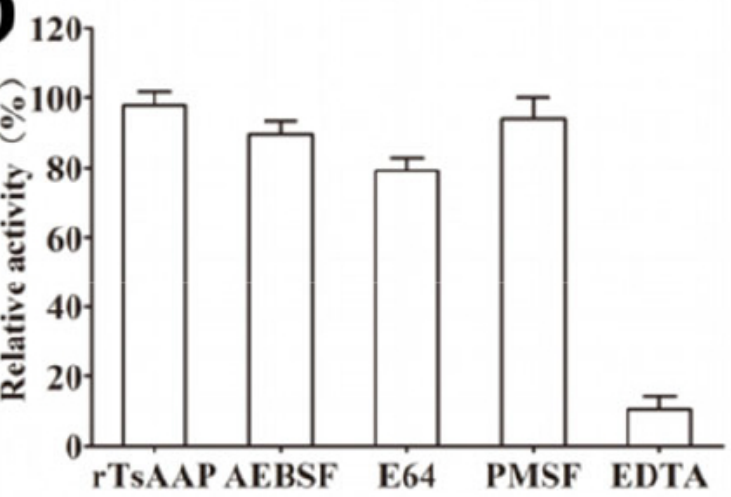

$\mathrm{E}$
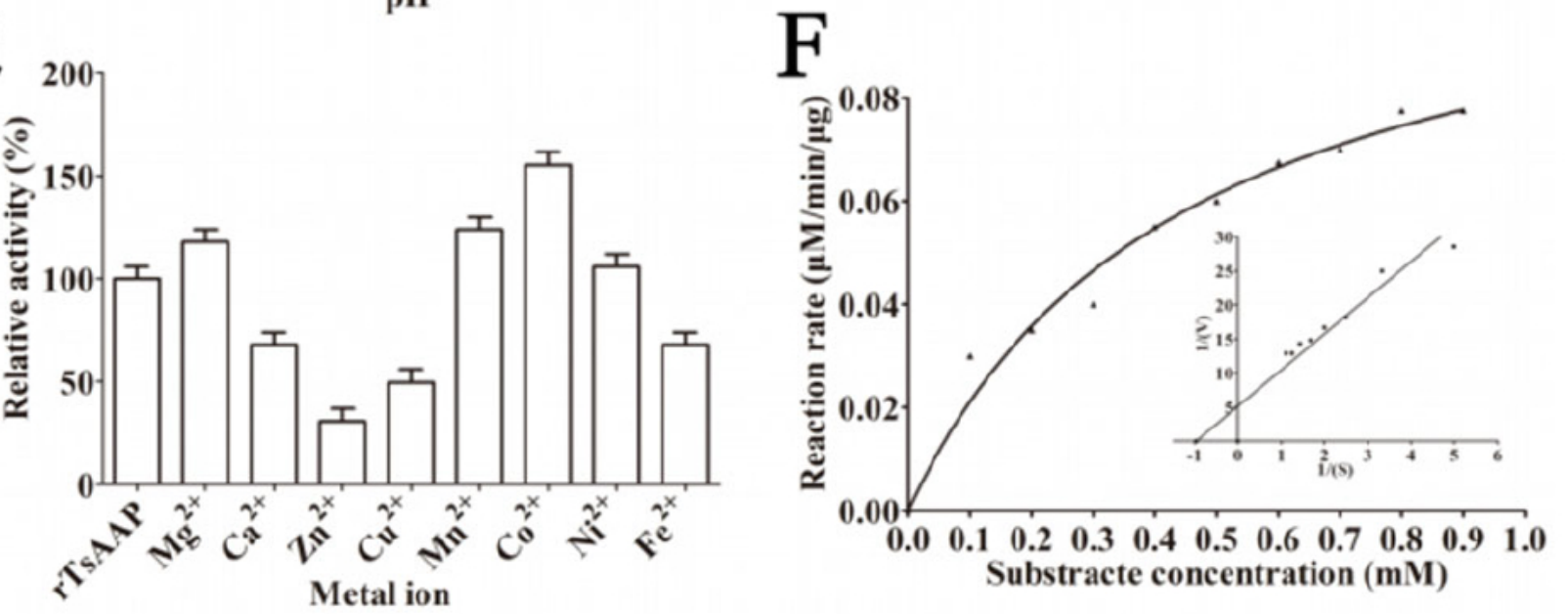

Figure 5. rTsAAP enzyme activity. A: The optimal enzyme amount for rTsAAP to hydrolyze the substrate; B: rTsAAP enzyme activity at different temperatures; C: rTsAAP enzyme activity at different $\mathrm{pH}$ values; D: Effects of various inhibitors on rTsAAP enzyme activity; E: Effects of different metal ions on rTsAAP enzyme activity; F: Michaelis-Menten plot and Lineweaver-Burk plot.

by $15.69,22.14,29.77,67.88 \%(P<0.05)$, and TsAAP protein expression levels were decreased by $17.81,20.88,47.02$ and $58.56 \%$, respectively $(P<0.05)$ (Figure $8 \mathrm{~A}, 8 \mathrm{~B})$. On 1,2 and $3 \mathrm{~d}$ after interference with $60 \mathrm{ng} / \mu \mathrm{l}$ dsRNA-TsAAP, TsAAP transcription level was decreased by $29.07,59.84$ and $75.49 \%$ $(P<0.05)$, and TsAAP protein expression was inhibited by 26.31 , 33.11 and $85.47 \%$, respectively $(P<0.05)$ (Figure $8 C, 8 D)$. There was no significant change of $T$. spiralis cathepsin $L$ (TSCL) protein expression level in ML treated with dsRNA-TsAAP (Figure 8E), indicating that the dsRNA is TsAAP-specific.

Worm crude proteins were prepared after the ML treated with $60 \mathrm{ng} / \mu \mathrm{L}$ dsRNA-TsAAP was cultured for $3 \mathrm{~d}$, and incubated the TsAAP substrate (H-Glu-PNA). The results showed TsAAP enzymatic activity in soluble proteins of dsRNA-treated ML was decreased by $37.92 \%$ compared with in the PBS group ( $P$ $<0.05$ ) (Figure $8 \mathrm{~F}$ ).

Suppression of dsRNA-TsAAP on larval growth, development and fecundity

The mice infected with dsRNA-TsAAP treated ML showed a $21.93 \%$ adult reduction at $3 \mathrm{dpi}$ and a $31.46 \%$ adult reduction at $6 \mathrm{dpi}$, compared the PBS group $\left(F_{3 \mathrm{~d}}=3.684, F_{6 \mathrm{~d}}=8.942, P\right.$ $<0.05)$, and the control dsRNA groups did not exhibited any adult burden reduction ( $P>0.05)$ (Figure 9). Female fecundity 


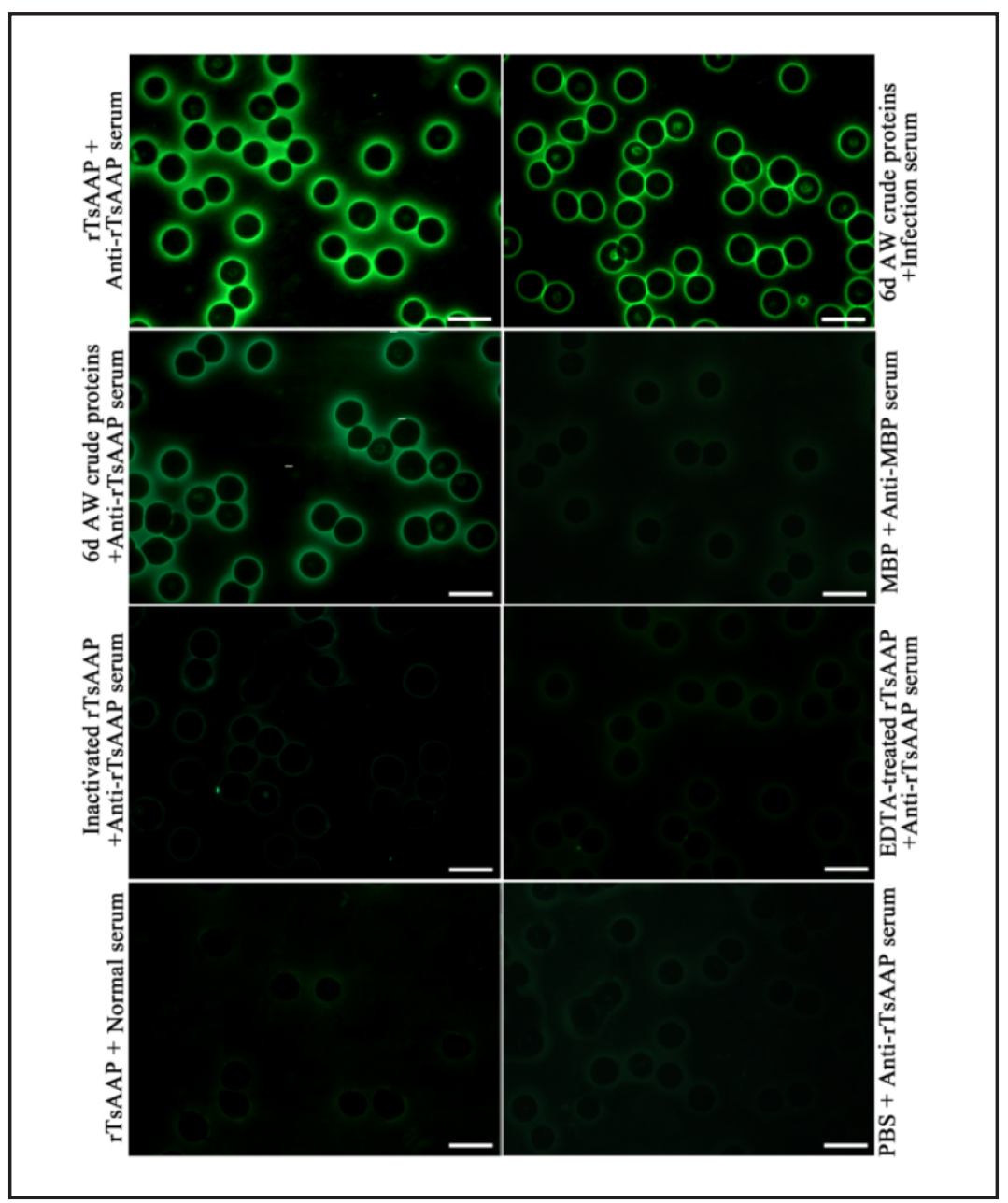

Figure 6. IIF assay of binding of rTSAAP and erythrocytes. IIF results indicated that the binding sites of rTsAAP and erythrocytes were on membrane of red blood cells. The erythrocytes incubating with crude adult protein were probed by anti-rTsAAP serum and infection serum as positive control, and MBP was used the irrelevant protein negative control. Scale bar: $20 \mu \mathrm{m}$.

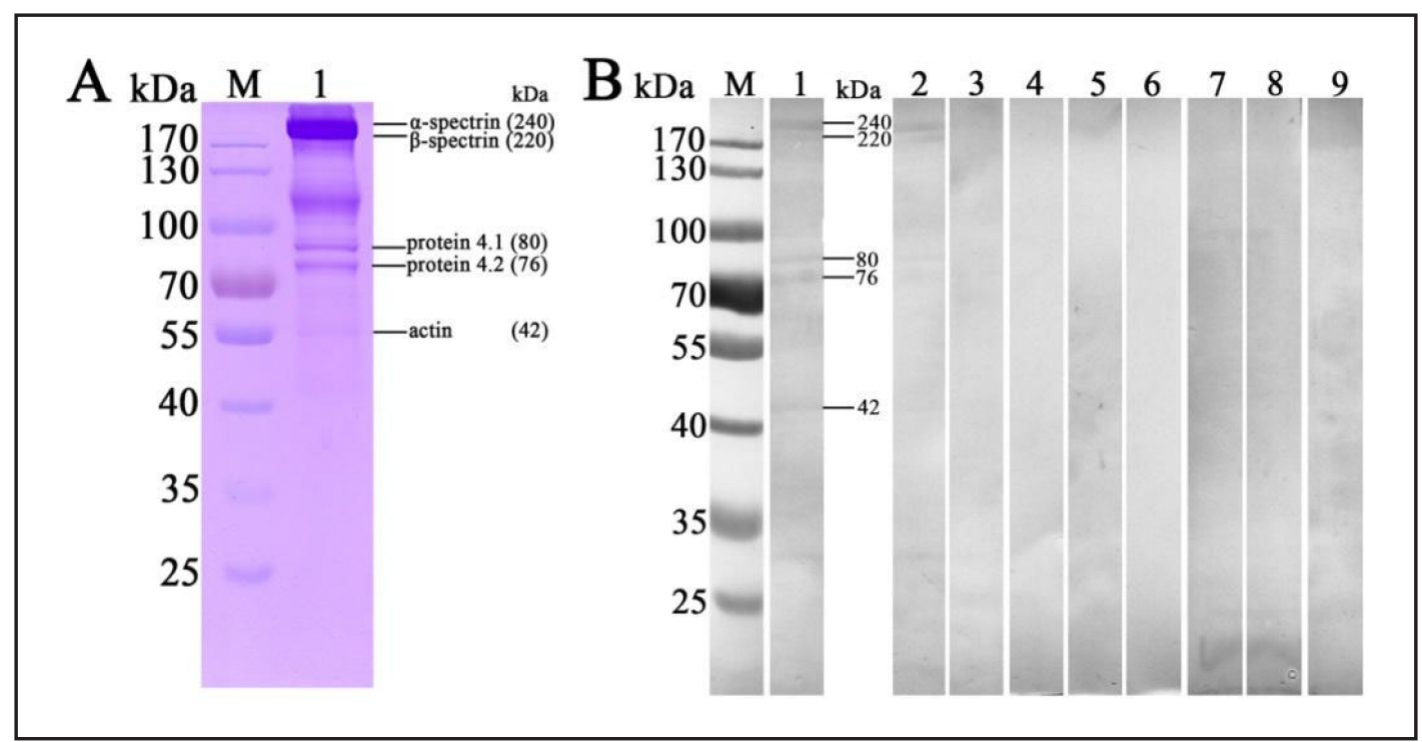

Figure 7. rTSAAP binds to erythrocyte membrane protein. A: SDS-PAGE of erythrocyte membrane proteins. M: protein marker; 1: erythrocyte membrane protein. B: Far-western blot of rTsAAP binding to erythrocyte membrane protein, $M$ : protein marker; 1-3: erythrocyte membrane proteins incubated with rTsAAP; 46: erythrocyte membrane protein incubated with MBP; 7-9 erythrocyte membrane protein incubated with PBS. 1 and 7: probed with anti-rTsAAP serum; 2, 5 and 8: probed with infection serum; 3, 6 and 9: probed with pre-immune serum; 4: probed with anti-MBP serum. 

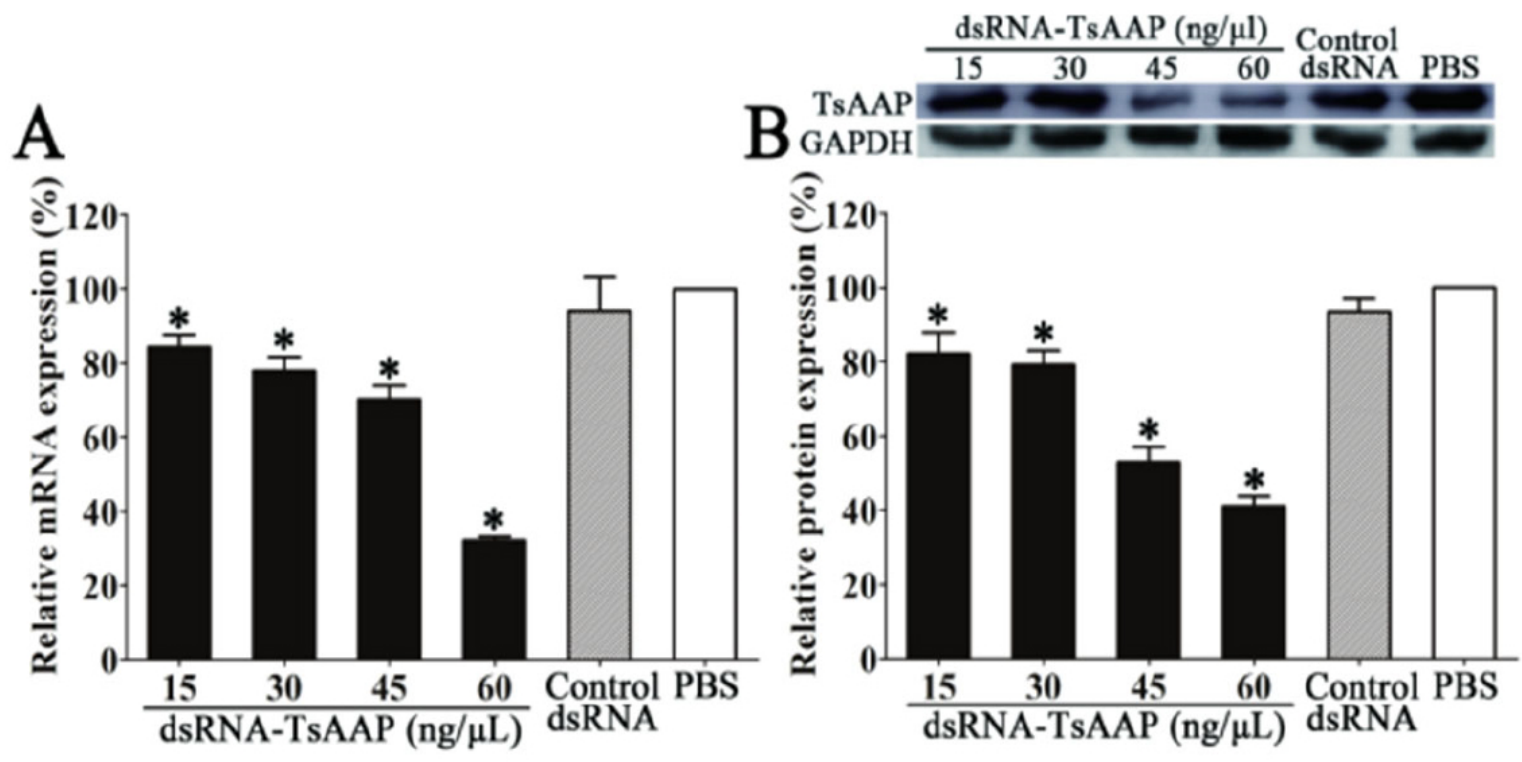

C

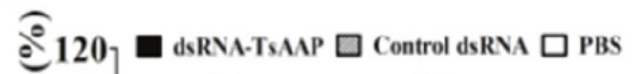

อे 120] dsRNA-TsAAP $\square$ Control dsRNA $\square$ PBS
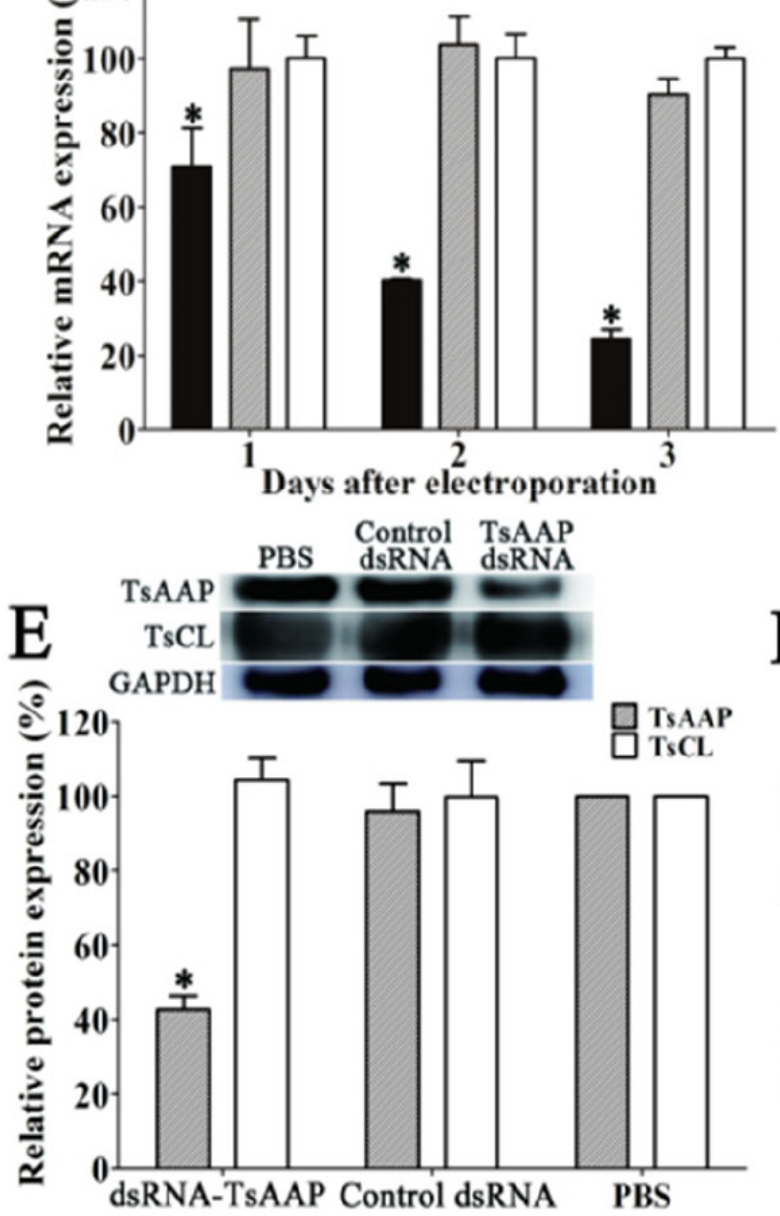

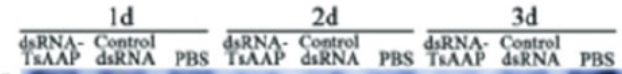

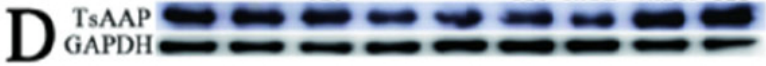

@120 — dsRNA-TsAAP $\square$ Control dsRNA $\square$ PBS

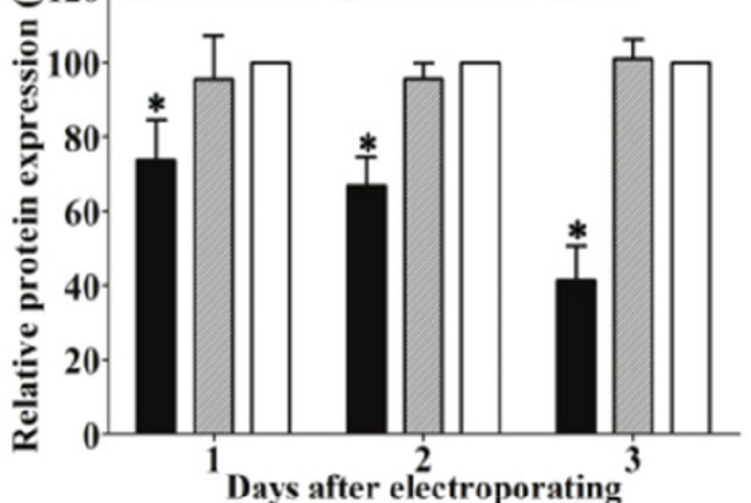

$\mathrm{F}$

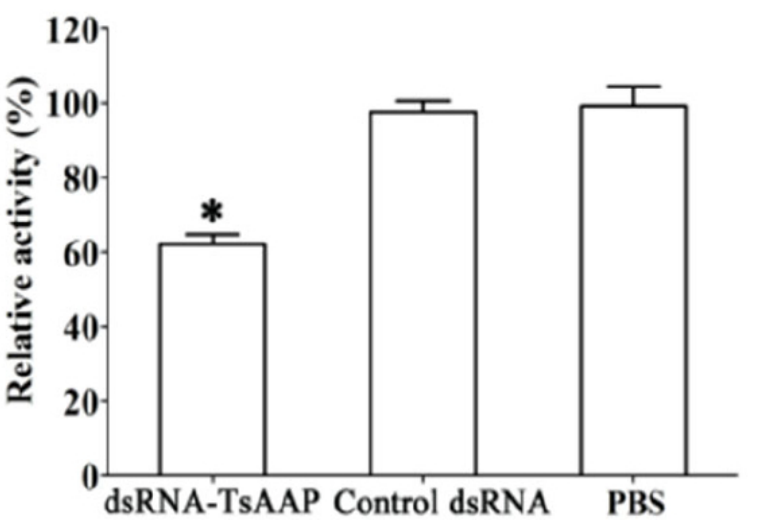

Figure 8. TsAAP transcription expression and enzyme activity after dsRNA interference. A: Effect of different dsRNA-TsAAP doses on TsAAP transcription level. B: Effect of different dsRNA-TsAAP doses on TsAAP expression level. C: TsAAP transcription levels at various days after dsRNA interference. D: TsAAP expression levels at various days after dsRNA interference. E: Expression levels of TsAAP and T. spiralis cathepsin L (TsCL) in ML treated using TsAAP-specific dsRNA. F: TsAAP enzymatic activity was significantly reduced in soluble proteins of dsRNA-TsAAP transfected $\mathrm{ML} .{ }^{*} P<0.05$ relative to the control dsRNA and PBS groups as negative controls. 

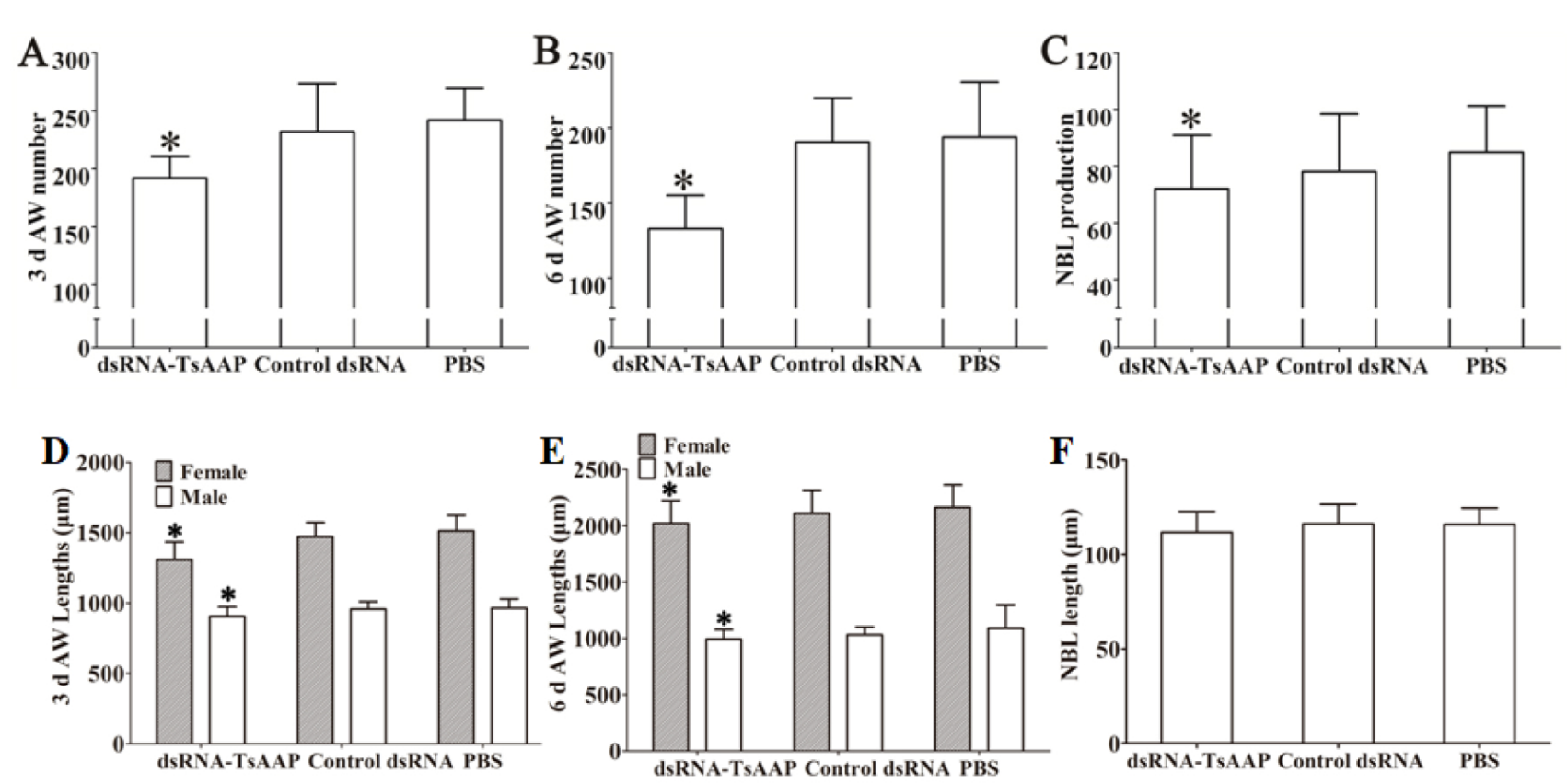

Figure 9. Intestinal adult worm burdens and lengths from mice challenged with muscle larvae transfected with dsRNA-TsAAP, control dsRNA or PBS. A: Intestinal adult worm burden at $3 \mathrm{dpi}$. B: Intestinal adult worm burden at 6 dpi. C: Newborn larvae (NBL) production of adult female adults in $72 \mathrm{~h}$. D: $3 \mathrm{~d}$ adult worm lengths. E: $6 \mathrm{~d}$ adult worm lengths. F: NBL lengths. ${ }^{*}$ Represents a significant difference compared with the control dsRNA and PBS groups as negative controls $(P<0.05)$.

in dsRNA-TSAAP treatment group was also evidently lower than the PBS group $(F=3.303, P<0.05)$, but there were no significant differences of female fecundity between control dsRNA and PBS group ( $P>0.05)$, suggested that silencing of TsAAP inhibited intestinal larval development and reduced the female fecundity.

Furthermore, compared with the PBS group, the length of female and male worms at $3 \mathrm{dpi}$ in dsRNA-TsAAP group was decreased by 13.35 and $15.25 \%$, respectively, $(P<0.05)$, the female and male length at $6 \mathrm{dpi}$ was decreased by 6.56 and $8.76 \%(P<0.05)$, but the newborn larval length had no significant change $(P>0.05)$, further conformed that silencing of TSAAP impaired intestinal larval growth and development.

\section{DISCUSSION}

Various $T$. spiralis enzymes play important roles in penetration, migration, feeding, parasitism and escape from host immune response (Ren et al., 2021). These enzyme molecules are usually stage-specific during the growth and development of $T$. spiralis, which may be related to the destruction of host mechanical barrier and humoral barrier (Ros-Moreno et al., 2000; Nagano et al., 2009). Most of enzymes had good antigenicity and have been proven to induce effective protective immunity against Trichinella infection and regarded as candidate vaccine target molecules (Zhang et al., 2018). At present, studies on T. spiralis enzymes mainly focuses on the serine proteases (Sun et al., 2018a), cysteine proteases (Song et al., 2018a; Yan et al., 2021), metalloprotease, aspartic proteases, and so on (Xu et al., $2020 \mathrm{~b})$, but there are only a few of studies on the peptidase function in lifecycle of $T$. spiralis. Previous studies showed that $T$. spiralis aminopeptidase is a potential candidate target for anti-Trichinella vaccine (Guo et al., 2020).

In this study, a TSAAP was cloned into pQE-80L plasmid and expressed in E. coli expression system. Bioinformatics analysis showed that TsAAP contained a Peptidase_M18 domain, which has the function of catalysis of the hydrolysis of $\mathrm{N}$-terminal amino acid residues. Sequence analysis showed that TSAAP had $94-99 \%$ identity with AAP of the 8 encapsulated species of the genus Trichinella, suggesting that AAP of many members of the M18 family have high homology, and their sequences are highly conserved. The phylogenetic tree demonstrated that a monophyletic group of 12 species/ genotypes of the genus Trichinella. After being purified, the rTsAAP was used to generate anti-rTsAAP immune serum. Immunization of mice with rTsAAP triggered an evidently specific anti-rTsAAP antibody response, and the titre of antirTsAAP IgG in immune serum was $1: 10^{4}$, demonstrating that rTsAAP had good immunogenicity.

The RT-PCR results showed TSAAP mRNA transcription was observed in various $T$. spiralis stages (ML, IIL, 3- and 6-day-old AWs, and NBL). On Western blotting analysis, rTsAAP was recognized by anti-rTsAAP serum and anti-his McAb, but no by Trichinella-infected mouse serum. Western blotting also revealed that natural TsAAP protein band with $51.76 \mathrm{kDa}$ in soluble crude proteins of various stage worms were recognized by anti-rTsAAP serum, demonstrating that TsAAP protein was expressed in various Trichinella developmental phases. The results of IIF using whole worms revealed that natural TsAAP was expressed on epicuticle of various $T$. spiralis lifecycle stages other than muscle larvae. The IIF with worm cross sections showed that TSAAP was principally localized at the cuticle, stichosome and female intrauterine embryos of the parasite. Moreover, native TSAAP in ML ES proteins was not recognized by anti-rTsAAP serum (data not shown), suggesting that TsAAP is a surface and somatic protein, but not secretory protein of this nematode. The purified rTsAAP was not recognized by $T$. spiralis infected serum on Western blotting and there was no fluorescence on ML stage by IIF, it is likely because the TSAAP is a worm somatic protein, and neither an ES protein nor a surface protein. The native somatic 
TsAAP is not exposed directly to host immune system and could not stimulate the host to produce a high level of antiTsAAP antibodies during natural $T$. spiralis infection (Li et al., 2015). The results suggested that TsAAP may play a role in intestinal worm and NBL growth and development in $T$. spiralis life cycle.

Enzymatic activity assay indicated that rTsAAP has the enzymatic activity of native AAP to hydrolyze the substrate $\mathrm{H}$ Glu-pNA. The optimal temperature and $\mathrm{pH}$ value of rTsAAP was $37^{\circ} \mathrm{C}$ and $\mathrm{pH} 7.5$, which is similar with that of $P$. falciparum aspartyl aminopeptidase (Lauterbach \& Coetzer, 2008). The rTsAAP activity was obviously enhanced by four metal ions $\left(\mathrm{Co}^{2+}, \mathrm{Mn}^{2+}, \mathrm{Mg}^{2+}\right.$ and $\left.\mathrm{Ni}^{2+}\right)$, and $\mathrm{Co}^{2+}$ was the most effective metal ion cofactor of rTsAAP, further verifying that TsAAP is a aminopeptidase which requires divalent metal cations and an optimal basic pH for the hydrolysis (Chen et al., 2012; Zheng et al., 2016). Besides, other four metal ions $\left(\mathrm{Ca}^{2+}, \mathrm{Zn}^{2+}\right.$, $\mathrm{Cu}^{2+}$ and $\mathrm{Fe}^{2+}$ ) have obvious inhibitory effect on rTsAAP activity. Excess zinc usually inhibits the enzymatic activity of peptidases, it is likely because only weakly hydrophobic interactions between proteolytic regions can loosely bind together to form tetrahedral pyramids. Excess zinc will lead to the disintegration of the dimer complex and destroy the quaternary structure of peptidases (Barrett, 1994; Park et al., 2017). Similar to other aspartyl aminopeptidase, rTsAAP is sensitive to metalloproteinase inhibitor (EDTA). Cysteine proteinase inhibitor (E64) and serine protease inhibitors (PMSF and AEBSF) have little effect on rTsAAP activity. These results indicated that $\mathrm{rTSAAP}$ is a metalloproteinase, and its enzyme activity is dependent on divalent metal ions and can be inhibited by metalloproteinase inhibitors (Guo et al., 2020).

In this study, the protein-protein interaction between rTsAAP and erythrocyte proteins was also evaluated. The IIF results revealed that there is a strong specific binding between rTsAAP and surface of erythrocyte membrane. Far-western analysis showed that rTsAAP can specifically bind to five kinds of erythrocyte membrane proteins ( $\alpha$-spectrin, $\beta$-spectrin, protein 4.1 , protein 4.2 , and actin). The $\alpha$-spectrin and $\beta$-spectrin are macromolecular heterotetramers composed of $\alpha$ and $\beta$ subunits in the cytoskeleton. The importance of spectrin in maintaining cell shape, mechanical properties and integrity of cell membranes has been clarified by many studies on red blood cells (Machnicka et al., 2019). Previous studies have shown that mutations in the spectrin protein in red blood cells can make the cells more fragile and less flexible, and lead to hereditary hemolytic anemia (Bennett \& Healy, 2008). The enhanced saliva acidification of spectrin in erythrocytes in visceral leishmaniasis patients may be related to the rupture of spectrin, leading to severe distortion of erythrocyte development and impaired integrity of erythrocyte membrane (Samanta et al., 2011). Protein 4.1 contains spectrin-actin binding domain ( $S A B$ ), which serves as a membranecytoskeleton crosslinking agent to connect spectrin-actin filament complex and a variety of transmembrane proteins. The formation of the ternary-complex between protein 4.1, spectrin-actin and actin effectively enhances the interaction between spectrin and actin (Baines et al., 2014). Actin is a class of multifunctional globular proteins that form microfilaments. It has a dynamic structure that can be assembled and disassembled. Erythrocyte actin filaments provide more sites for the spectrin-actin filament complex to connect to the lipid bilayer (Gokhin \& Fowler, 2016).

AAP can specifically remove glutamate and aspartic acid at the $\mathrm{N}$-terminal of the peptide chain. It has been found that actin and $\alpha$-spectrin have three aspartic acids (actin) and one glutamic acid ( $\alpha$-spectrin) following the $\mathrm{N}$-terminal methionine (Bradshaw et al., 1998). Aspartic acid or glutamic acid near the $\mathrm{N}$-termini of $\beta$-spectrin, protein 4.1 and protein 4.2 may be the primary targets of TsAAP (Teuscher et al., 2007). All the above proteins are important components of the cytoskeleton system of cell membranes. Actin and protein 4.1 are located in the junction complex, and protein 4.2 is located in the band 3 complex of the erythrocyte membrane. Actin and protein 4.1 are located in the junction complex, and protein 4.2 is located in the band 3 complex of the erythrocyte membrane (Tse \& Lux, 1999). Thus, cleavage of any of these proteins can destabilize the cytoskeleton of the erythrocyte membrane. $P$. falciparum AAP is involved in the digestion of hemoglobin in food vacuoles by cleavage of membrane skeleton proteins (e.g., spectrin) (Lauterbach \& Coetzer, 2008). P. falciparum digest hemoglobin into peptides, which are converted into single amino acids by the combined action of AAP and other aminopeptidases (Dalal \& Klemba, 2007). So hemoglobin is an important nutrient source of amino acids in parasites. T. spiralis mainly obtain nutrition from the body fluid and tissue fluid of the host. Although it is not a blood-sucking nematode, there is a large amount of hemoglobin in its pseudocelom of the parasite. Hemoglobin and oxyhemoglobin had been identified in Trichinella larvae. Unlike most other parasite hemoglobin, the hemoglobin found in larvae has a very low affinity for oxygen. Hemoglobin appears to accumulate gradually in larvae, and the encapsulated larvae that have resided in skeletal muscles for over 6 weeks have more hemoglobin than younger worms (Campbell et al., 1983). It has been found that Caenorhabditis elegans can ingest and digest fluorescently labeled erythrocytes at all stages of parasitic feeding. The nematode uses the suction force of the pharyngeal pump to capture the red blood cells, which rupture and release their contents. The contents of the red blood cells enter the intestine through the pharynx, and the nematode can survive on the red blood cells (Chauhan \& Pritchard, 2019). Therefore, it is speculated that TSAAP may have a similar physiological activity to hydrolyze hemoglobin to free amino acids through proteolytic cascade reaction. Aminopeptidase plays a key role in protein turnover and regulation of intracellular amino acid library. They are essential for the metabolism, growth and development of all cells and tissues, (Mucha et al., 2010). As an intracellular peptidase, AAP may play a role in the last step of the cascade reaction, producing free aspartic acid and glutamic acid for $T$. spirais to synthesize the macromolecules. The results suggested that $T$. spiralis might destroy the erythrocyte membrane through interaction between TSAAP and erythrocyte membrane skeleton proteins, hydrolyze hemoglobin into free amino acids with the participation of TSAAP, and consequently get nutrition for maintaining the worm growth and development.

RNA interference (RNAi) technique was extensively used in many organisms to identify genes involved in regeneration and development and to provide information about gene function (Fischer, 2015). In recent years, RNAi has been applied to study the function of Trichinella genes (Wang et al., 2015; Xu et al., 2020b; Yang et al., 2020a). In this study, TsAAPspecific dsRNA was designed on the basis of Peptidase_M18 functional domain of TsAAP. dsRNA-TSAAP was delivered into the $\mathrm{ML}$ by electroporation, the results showed that $60 \mathrm{ng} / \mu \mathrm{L}$ dsRNA treatments for 3 days had the ideal interference effect, the TSAAP expression and enzymatic activity in dsRNAtransfected ML was decreased by $85.47 \%$ and $37.92 \%$ respectively. After silencing the TsAAP gene, worm burdens of intestinal adult worms recovered from infected mice at 3 and $6 \mathrm{dpi}$ were significantly decreased, the length of adult 
worms became shorter, and the fecundity of $6 \mathrm{~d}$ female worms was distinctly reduced. The results suggested that silencing of TsAAP gene might impair $T$. spiralis nourishment uptake, significantly impede worm growth and development, and inhibited female reproduction capacity (Yang et al., 2020b).

In conclusion, TsAAP was transcribed and expressed in all stages of $T$. spiralis lifecycle. It was principally located at cuticle, stichosome and intrauterine embryos of this nematode. rTsAAP had good immunogenicity. rTsAAP has an enzymatic activity of a natural aspartyl aminopeptidase. rTsAAP has the capacity to specifically bind to erythrocyte membrane proteins. Silencing of TsAAP gene by specific dsRNA obviously reduced the levels of TsAAP transcription, expression and enzymatic activity. RNAi also significantly decreased intestinal worm burdens, worm length and female fecundity, suggested that TsAAP might play an important role to provide the parasite with nourishment. The results indicated that TSAAP participates in the growth, development and fecundity of $T$. spiralis and it might be a potential candidate target for anti-Trichinella vaccine and therapeutic drug.

\section{ACKNOWLEDGEMENTS}

This study was supported by grants of the National Natural Science Foundation of China (U1704189).

\section{Conflicts of interest}

The authors declare no conflicts of interest with regards to this study or the manuscript prepared for publication.

\section{REFERENCES}

Bai, X., Hu, X., Liu, X., Tang, B. \& Liu, M. (2017). Current research of trichinellosis in China. Frontiers in Microbiology 8: 1472. https://doi.org/10.3389/fmicb.2017.01472

Baines, A.J., Lu, H.C. \& Bennett, P.M. (2014). The Protein 4.1 family: hub proteins in animals for organizing membrane proteins. Bio ${ }^{\circ}$ himica et Biophysica Acta 1838: 605-619. https://doi.org/10.1016/j.bbamem.2013.05.030

Barrett, A.J. (1994). Classification of peptidases. Methods in Enzymology 244: 1-15. https://doi.org/10.1016/0076-6879(94) 44003-4

Bennett, V. \& Healy, J. (2008). Organizing the fluid membrane bilayer: diseases linked to spectrin and ankyrin. Trends in Molecular Medicine 14: 28-36. https://doi.org/10.1016/ j.molmed.2007.11.005

Bradshaw, R.A., Brickey, W.W. \& Walker, K.W. (1998). N-terminal processing: the methionine aminopeptidase and $\mathrm{N}$ alpha-acetyl transferase families. Trends in Biochimical sciences 23: 263-267. https://doi.org/10.1016/s0968-0004(98) 01227-4

Campbell, W.C. (1983). Trichinella and Trichinosis. New York: Plenum Press.

Chauhan, V.M. \& Pritchard, D.I. (2019). Haematophagic Caenorhabditis elegans. Parasitology 146: 314-320. https:// doi.org/10.1017/S0031182018001518

Chen, Y., Farquhar, E.R., Chance, M.R., Palczewski, K. \& Kiser, P.D. (2012). Insights into substrate specificity and metal activation of mammalian tetrahedral aspartyl aminopeptidase. Journal of Biological Chemistry 287: 13356-13370. http://doi.org/ 10.1074/jbc.M112.347518

Coetzer, T.L. \& Palek, J. (1986). Partial spectrin deficiency in hereditary pyropoikilocytosis. Blood 67: 919-924. https:// doi.org/10.1182/blood.V67.4.919.919
Cui, J., Han, Y., Yue, X., Liu, F., Song, Y.Y., Yan, S.W., Lei, J.J., Zhang, X., Jiang, P. \& Wang, Z.Q. (2019). Vaccination of mice with a recombinant novel cathepsin B inhibits Trichinella spiralis development, reduces the fecundity and worm burden. Parasites \& Vectors 12: 581. http://doi.org/10.1186/ s13071-019-3833-9

Cui, J., Jiang, P., Liu, L.N. \& Wang, Z.Q. (2013a). Survey of Trichinella infections in domestic pigs from northern and eastern Henan, China. Veterinary Parasitology 194: 133-135. http:// doi.org/10.1016/j.vetpar.2013.01.038

Cui, J., Li, L.G., Jiang, P., Liu, R.D., Yang, X., Liu, L.N., Liu, P., Zhang, S.B. \& Wang, Z.Q. (2015a) Biochemical and functional characterization of the glutathione Stransferase from Trichinella spiralis. Parasitology Research 114: 2007-2013. http://doi.org/10.1007/s00436-015-4410-6

Cui, J., Ren, H.J., Liu, R.D., Wang, L., Zhang, Z.F. \& Wang, Z.Q. (2013b). Phage-displayed specific polypeptide antigens induce significant protective immunity against Trichinella spiralis infection in BALB/c mice. Vaccine 31: 1171-1177. https://doi.org/10.1016/j.vaccine.2012.12.070

Cui, J., Wang, L., Sun, G.G., Liu, L.N., Zhang, S.B., Liu, R.D., Zhang, X., Jiang, P. \& Wang, Z.Q. (2015b). Characterization of a Trichinella spiralis $31 \mathrm{kDa}$ protein and its potential application for the serodiagnosis of trichinellosis. Acta Tropica 142: 57-63. https://doi.org/10.1016/j.actatropica. 2014.10.017

Cui, J., Wang, Z.Q. \& Xu, B.L. (2011). The epidemiology of human trichinellosis in China during 2004-2009. Acta Tropica 118: 1-5. https://doi.org/10.1016/j.actatropica.2011.02.005

Dalal., S. \& Klemba, M. (2007). Roles for two aminopeptidases in vacuolar hemoglobin catabolism in Plasmodium falciparum. Journal of Biological Chemistry 282: 35978-35987. https://doi.org/10.1074/jbc.M703643200

Fischer, S.E.J. (2015). RNA interference and microRNAmediated silencing. Current Protocols in Molecular Biology 112: 26.1.1-26.1.5. https://doi.org/10.1002/0471142727. $\mathrm{mb} 2601 \mathrm{~s} 112$

Gokhin, D.S. \& Fowler, V.M. (2016). Feisty filaments: actin dynamics in the red blood cell membrane skeleton. Current Opinion in Hematology 23: 206-214. https://doi.org/ 10.1097/MOH.0000000000000227

Guo, K.X., Bai, Y., Ren, H.N., Sun, X.Y., Song, Y.Y., Liu, R.D., Long, S.R., Zhang, X., Jiang, P., Wang, Z.Q. et al. (2020). Characterization of a Trichinella spiralis aminopeptidase and its participation in invasion, development and fecundity. Veterinary Research 51: 78. https://doi.org/10.1186/ s13567-020-00805-w

Han, Y., Yue, X., Hu, C.X., Liu, F., Liu, R.D., He, M.M., Long, S.R., Cui, J. \& Wang, Z.Q. (2020). Interaction of a Trichinella spiralis cathepsin B on enterocytes promotes the larval intrusion into the cells. Research in Veterinary Science 130: 110-117. https://doi.org/10.1016/j.rvsc.2020.03.012

Hu, C.X., Jiang, P., Yue, X., Zeng, J., Zhang, X.Z., Song, Y.Y., Liu, R.D., Zhang, X., Wang, Z.Q. \& Cui, J. (2020a). Molecular characterization of a Trichinella spiralis elastase-1 and its potential as a diagnostic antigen for trichinellosis. Parasites \& Vectors 13: 97. https://doi.org/10.1186/s13071020-3981-y

Hu, C.X., Zeng, J., Yang, D.Q., Yue, X., Liu, R.D., Long, S.R., Zhang, X., Jiang, P., Cui, J. \& Wang, Z.Q. (2020b). Binding of elastase1 and enterocytes facilitates Trichinella spiralis larval intrusion of the host's intestinal epithelium. Acta Tropica 211: 105592. https://doi.org/10.1016/j.actatropica.2020. 105592 
Jiang, P., Wang, Z.Q., Cui, J. \& Zhang, X. (2012). Comparison of artificial digestion and Baermann's methods for detection of Trichinella spiralis pre-encapsulated larvae in muscles with low-level infections. Foodborne Pathogens and Disease 9: 27-31. https://doi.org/10.1089/fpd.2011.0985

Jiang, P., Zhang, X., Wang, L.A., Han, L.H., Yang, M., Duan, J.Y., Sun, G.G., Qi, X., Liu, R.D., Wang, Z.Q. et al. (2016). Survey of Trichinella infection from domestic pigs in the historical endemic areas of Henan province, central China. Parasitology Research 115: 4707-4709. https://doi.org/10.1007/ s00436-016-5240-x

Kumari, M., Chandra, S., Tiwari, N. \& Subbarao, N. (2016). 3D QSAR, pharmacophore and molecular docking studies of known inhibitors and designing of novel inhibitors for M18 aspartyl aminopeptidase of Plasmodium falciparum. BMC Structural Biology 16: 12. https://doi.org/10.1186/ s12900-016-0063-7

Lauterbach, S.B. \& Coetzer, T.L. (2008). The M18 aspartyl aminopeptidase of Plasmodium falciparum binds to human erythrocyte spectrin in vitro. Malaria Journal 7: 161. https://doi.org/10.1186/1475-2875-7-161

Lei, J.J., Hu, Y.Y., Liu, F., Yan, S.W., Liu, R.D., Long, S.R., Jiang, P., Cu,i J. \& Wang, Z.Q. (2020). Molecular cloning and characterization of a novel peptidase from Trichinella spiralis and protective immunity elicited by the peptidase in BALB/c mice. Veterinary Research 51: 111. https://doi.org/ 10.1186/s13567-020-00838-1

Li, J.F., Guo, K.X., Qi, X., Lei, J.J., Han, Y., Yan, S.W., Jiang, P., Yu, C, Cheng, X.C., Wang, Z.Q. et al. (2018). Protective immunity against Trichinella spiralis in mice elicited by oral vaccination with attenuated Salmonella-delivered TsSP1.2 DNA. Veterinary Research 49: 87. http://doi.org/10.1186/ s13567-018-0582-2

Li, L.G., Wang, Z.Q., Liu, R.D., Yang, X., Liu, L.N., Sun, G.G., Jiang, P., Zhang, X., Zhang, G.Y. \& Cui, J. (2015). Trichinella spiralis: low vaccine potential of glutathione $\mathrm{S}$-transferase against infections in mice. Acta Tropica 146: 25-32. https://doi.org/ 10.1016/j.actatropica.2015.02.020

Liu, C.Y., Ren, H.N., Song, Y.Y., Sun, G.G., Liu, R.D., Jiang, P., Long, S.R., Zhang, X., Wang, Z.Q. \& Cui, J. (2018). Characterization of a putative glutathione S-transferase of the parasitic nematode Trichinella spiralis. Experimental Parasitology 187: 59-66. https://doi.org/10.1016/j.exppara.2018.02.005

Liu, C.Y., Song, Y.Y., Ren, H.N., Sun, G.G., Liu, R.D, Jiang, P., Long, S.R., Zhang, X., Wang, Z.Q. \& Cui, J. (2017). Cloning and expression of a Trichinella spiralis putative glutathione Stransferase and its elicited protective immunity against challenge infections. Parasites \& Vectors 10: 448. https:// doi.org/10.1186/s13071-017-2384-1

Liu, L.N., Wang, Z.Q., Zhang, X., Jiang, P., Qi, X., Liu, R.D., Zhang, Z.F. \& Cui, J. (2015a). Characterization of Spirometra erinaceieuropaei plerocercoid cysteine protease and potential application for serodiagnosis of sparganosis. PLoS Neglected Tropical Diseases 9: e0003807. https://doi.org/ 10.1371/journal.pntd.0003807

Liu, P., Cui, J., Liu, R.D., Wang, M., Jiang, P., Liu, L.N., Long, S.R., Li, L.G., Zhang, S.B., Zhang, X.Z. et al. (2015b). Protective immunity against Trichinella spiralis infection induced by TsNd vaccine in mice. Parasites \& Vectors 8: 185. https:// doi.org/10.1186/s13071-015-0791-8

Liu, P., Wang, Z.Q., Liu, R.D., Jiang, P., Long, S.R., Liu, L.N., Zhang, X.Z., Cheng, X.C., Yu, C., Ren, H.J. et al. (2015c). Oral vaccination of mice with Trichinella spiralis nudix hydrolase DNA vaccine delivered by attenuated Salmonella elicited protective immunity. Experimental Parasitology 153: 29-38. https://doi.org/10.1016/j.exppara.2015.02.008
Liu, R.D., Cui, J., Liu, X.L., Jiang, P., Sun, G.G., Zhang, X., Long, S.R., Wang, L. \& Wang, Z.Q. (2015d). Comparative proteomic analysis of surface proteins of Trichinella spiralis muscle larvae and intestinal infective larvae. Acta Tropica 150: 79-86. https://doi.org/10.1016/j.actatropica.2015.07.002

Liu, R.D., Qi, X., Sun, G.G., Jiang, P., Zhang, X., Wang, L.A., Liu, X.L., Wang, Z.Q. \& Cui, J. (2016). Proteomic analysis of Trichinella spiralis adult worm excretory-secretory proteins recognized by early infection sera. Veterinary Parasitology 231: 43-46. https://doi.org/10.1016/j.vetpar.2016.10.008

Liu, R.D., Wang, Z.Q., Wang, L., Long, S.R., Ren, H.J. \& Cui, J. (2013). Analysis of differentially expressed genes of Trichinella spiralis larvae activated by bile and cultured with intestinal epithelial cells using real-time PCR. Parasitology Research 112: 4113-4120. https://doi.org/ 10.1007/s00436-013-3602-1

Long, S.R., Wang, Z.Q., Jiang, P., Liu, R.D., Qi. X., Liu, P., Ren, H.J., Shi. H.N. \& Cui, J. (2015). Characterization and functional analysis of Trichinella spiralis Nudix hydrolase. Experimental Parasitology 159: 264-273. https://doi.org/10.1016/j.exppara. 2015.10.009

Machnicka, B., Grochowalska, R., Boguslawska, D.M. \& Sikorski, A.F. (2019). The role of spectrin in cell adhesion and cell-cell contact. Experimental Biology and Medicine 244: 1303-1312. https://doi.org/10.1177/1535370219859003

Mitreva, M., Jasmer, D.P., Zarlenga, D.S., Wang, Z., Abubucker, S., Martin, J., Taylor, C.M., Yin, Y., Fulton, L., Minx, P. et al. (2001). The draft genome of the parasitic nematode Trichinella spiralis. Nature Genetics 43: 228-235. https:// doi.org/10.1038/ng.769

Mucha, A., Drag, M., Dalton, J.P. \& Kafarski, P. (2010). Metalloaminopeptidase inhibitors. Biochimie 92: 1509-1529. https://doi.org/10.1016/j.biochi.2010.04.026

Nagano, I., Wu, Z. \& Takahashi, Y. (2009) Functional genes and proteins of Trichinella spp. Parasitology Research 104: 197-207. https://doi.org/10.1007/s00436-008-1248-1

Park, S.Y., Scranton, M.A., Stajich, J.E., Yee, A. \& Walling, L.L. (2017). Chlorophyte aspartyl aminopeptidases: Ancient origins, expanded families, new locations, and secondary functions. PLOS ONE 12: e0185492. https://doi.org/10.1371/ journal.pone. 0185492

Pozio, E. (2005). The broad spectrum of Trichinella hosts: From cold- to warm-blooded animals. Veterinary Parasitology 132: 3-11. https://doi.org/10.1016/j.vetpar.2005.05.024

Qi, X., Han, Y., Jiang, P., Yue, X., Ren, H.N., Sun, G.G., Long, S.R., Yu, C., Cheng, X.C., Cui, J. et al. (2018a). Oral vaccination with Trichinella spiralis DNase II DNA vaccine delivered by attenuated Salmonella induces a protective immunity in BALB/c mice. Veterinary Research 49: 119. https://doi.org/ 10.1186/s13567-018-0614-y

Qi, X., Yue, X., Han, Y., Jiang, P., Yang, F., Lei, J.J., Liu, R.D., Zhang, X., Wang, Z.Q. \& Cui, J. (2018b). Characterization of two Trichinella spiralis adult-specific DNase II and their capacity to induce protective immunity. Frontiers in Microbiology 9: 2504. https://doi.org/10.3389/fmicb.2018.02504

Ren, H.J., Cui, J., Wang, Z.Q. \& Liu, R.D. (2011). Normal mouse intestinal epithelial cells as a model for the in vitro invasion of Trichinella spiralis infective larvae. PLOS ONE 6: e27010. https://doi.org/10.1371/journal.pone.0027010

Ren, H.N., Liu, R.D., Song, Y.Y., Zhuo, T.X., Guo, K.X., Zhang, Y., Jiang, P., Wang, Z.Q. \& Cui, J. (2019). Label-free quantitative proteomic analysis of molting-related proteins of Trichinella spiralis intestinal infective larvae. Veterinary Research 50: 70. https://doi.org/10.1186/s13567-0190689-0 
Ren, H.N., Zhuo, T.X., Bai, S.J., Bai, Y., Sun, X.Y., Liu, R.D., Long, S.R., Cui, J. \& Wang, Z.Q. (2021). Proteomic analysis of hydrolytic proteases in excretory/secretory proteins from Trichinella spiralis intestinal infective larvae using zymography combined with shotgun LC-MS/MS approach. Acta Tropica 216: 105825. https://doi.org/10.1016/j.acta tropica.2021.105825

Ros-Moreno, R.M., Vázquez-López, C., Giménez-Pardo, C., Armas-Serra, de.C. \& Rodríguez-Caabeiro, F. (2000). A study of proteases throughout the life cycle of Trichinella spiralis. Folia Parasitologica 47: 49-54. https://doi.org/10.14411/fp. 2000.009

Rostami, A., Gamble, H.R., Dupouy-Camet, J., Khazan, H. \& Bruschi, F. (2017). Meat sources of infection for outbreaks of human trichinellosis. Food Microbiology 64: 65-71. https://doi.org/10.1016/j.fm.2016.12.012

Rout, S. \& Mahapatra, R.K. (2019). In silico study of M18 aspartyl amino peptidase (M18AAP) of Plasmodium vivax as an antimalarial drug target. Bioorganic \& Medicinal Chemistry 27: 2553-2571. https://doi.org/10.1016/j.bmc.2019.03.039

Samanta, S., Dutta, D., Ghoshal., A., Mukhopadhyay, S., Saha, B., Sundar, S., Jarmalavicius, S., Forgber, M., Mandal., C., Walden, P. et al. (2011). Glycosylation of erythrocyte spectrin and its modification in visceral leishmaniasis. PLOS ONE 6: e28169. https://doi.org/10.1371/journal.pone. 0028169

Song, Y.Y., Wang, L.A., Ren, H.N., Qi, X., Sun, G.G., Liu, R.D., Jiang, P., Zhang, X., Cui, J. \& Wang, Z.Q. (2018a). Cloning, expression and characterisation of a cysteine protease from Trichinella spiralis. Folia Parasitologica 65: 007. https:// doi.org/10.14411/fp.2018.007

Song, Y.Y., Zhang, Y., Yang, D.Q., Ren, H.N., Sun, G.G., Jiang, P., Liu, R.D., Zhang, X., Cui, J. \& Wang, Z.Q. (2018b). The immune protection induced by a serine protease inhibitor from the foodborne parasite Trichinella spiralis. Frontiers in Microbiology. 9: 1544. https://doi.org/10.3389/fmicb.2018. 01544

Sun, G.G., Lei, J.J., Ren, H.N., Zhang, Y., Guo, K.X., Long, S.R., Liu, R.D., Jiang, P., Wang, Z.Q. \& Cui, J. (2019). Intranasal immunization with recombinant Trichinella spiralis serine protease elicits protective immunity in BABL/c mice. Experimental Parasitology 201: 1-10. https://doi.org/10.1016/ j.exppara.2019.04.006

Sun, G.G., Ren, H.N., Liu, R.D., Song, Y.Y., Qi, X., Hu, C.X., Yang, F., Jiang, P., Zhang, X., Wang, Z.Q. et al. (2018a). Molecular characterization of a putative serine protease from Trichinella spiralis and its elicited immune protection. Veterinary Research 49: 59. https://doi.org/10.1186/s13567018-0555-5

Sun, G.G., Song, Y.Y., Jiang, P., Ren, H.N., Yan, S.W., Han, Y., Liu, R.D., Zhang, X., Wang, Z.Q. \& Cui, J. (2018b). Characterization of a Trichinella spiralis putative serine protease. Study of its potential as serodiagnostic tool. PLoS Neglected Tropical Diseases 12: e0006485. https://doi.org/10.1371/journal. pntd.0006485

Sun, G.G., Wang, Z.Q., Liu, C.Y., Jiang, P., Liu, R.D., Wen, H., Qi, X., Wang, L. \& Cui, J. (2015). Early serodiagnosis of trichinellosis by ELISA using excretory-secretory antigens of Trichinella spiralis adult worms. Parasites \& Vectors 8: 484. https://doi.org/10.1186/s13071-015-1094-9

Teuscher, F., Lowther, J., Skinner-Adams, T.S., Spielmann, T., Dixon, M.W., Stack, C.M., Donnelly, S., Mucha, A., Kafarski, P., Vassiliou, S. et al. (2007). M18 aspartyl aminopeptidase of the human malaria parasite Plasmodium falciparum. Journal of Biological Chemistry 282: 30817-30826. https:// doi.org/10.1074/jbc.M704938200
Tse, W.T. \& Lux, S.E. (1999). Red blood cell membrane disorders. Brtish Journal of Haematology 104: 2-13. https://doi.org/ 10.1111/j.1365-2141.1999.01130.x

Walling, L.L. (2006). Recycling or regulation? The role if aminoterminal modifying enzymes. Current Opinion in Plant Biology 9: 227-233. https://doi.org/10.1016/j.pbi.2006.03.009

Wang, B., Wang, Z.Q., Jin, J., Ren, H.J., Liu, L.N. \& Cui, J. (2013a). Cloning, expression and characterization of a Trichinella spiralis serine protease gene encoding a $35.5 \mathrm{kDa}$ protein. Experimental Parasitology 134: 148-154. https://doi.org/ 10.1016/j.exppara.2013.03.004

Wang, L., Wang, Z.Q. \& Cui, J. (2013b). Protein changes in Trichinella spiralis muscle larvae in vitro induced by bovine bile. Veterinary Parasitology 194: 164-167. https://doi.org/ 10.1016/j.vetpar.2013.01.046

Wang, L., Wang, Z.Q. \& Cui, J. (2013c). Proteomic analysis of the changed proteins of Trichinella spiralis infective larvae after co-culture in vitro with intestinal epithelial cells. Veterinary Parasitology 194: 160-163. https://doi.org/10.1016/ j.vetpar.2013.01.045

Wang, Z.Q., Li, L.Z., Jiang, P., Liu, L.N. \& Cui, J. (2012). Molecular identification and phylogenetic analysis of Trichinella isolates from different provinces in mainland China. Parasitology Research 110: 753-757. https://doi.org/10.1007/ s00436-011-2549-3

Wang, Z.Q., Liu, R.D., Sun, G.G., Song, Y.Y., Jiang, P., Zhang, X. \& Cui, J. (2017). Proteomic analysis of Trichinella spiralis adult worm excretory-secretory proteins recognized by sera of patients with early trichinellosis. Frontiers in Microbiology 8: 986. https://doi.org/10.3389/fmicb.2017.00986

Wang, Z.Q., Zhang, S.B., Jiang, P., Liu, R.D., Long, S.R., Zhang, X., Ren, H.J. \& Cui, J. (2015). The siRNA-mediated silencing of Trichinella spiralis nudix hydrolase results in reduction of larval infectivity. Parasitology Research 114: 3551-3557. https://doi.org/10.1007/s00436-015-4650-5

Wilk, S., Wilk, E. \& Magnusson, R.P. (1998). Purification, characterization and cloning of a cytosolic aspartyl aminopeptidase. Journal of Biological Chemistry 273: 1596115970. https://doi.org/10.1074/jbc.273.26.15961

Wu, Z., Nagano, I., Takahashi, Y. \& Maekawa, Y. (2016). Practical methods for collecting Trichinella parasites and their excretory-secretory products. Parasitology International 65: 591-595. https://doi.org/10.1016/j. parint.2016.08.001

Xu, D., Tang, B., Wang, Y., Zhang, L., Qu, Z., Shi, W., Wang, X., Sun, Q., Sun, S. \& Liu, M. (2020a). The immune protection induced by a serine protease from the Trichinella spiralis adult administered as DNA and protein vaccine. Acta Tropica 211: 105622. https://doi.org/10.1016/j.actatropica. 2020.105622

Xu, J., Liu, R.D., Bai, S.J., Hao, H.N., Yue, W.W., Xu, Y.X.Y., Long, S.R., Cui, J. \& Wang, Z.Q. (2020b). Molecular characterization of a Trichinella spiralis aspartic protease and its facilitation role in larval invasion of host intestinal epithelial cells. PLoS Neglected Tropical Diseases 14: e0008269. https:// doi.org/10.1371/journal.pntd.0008269

Xu, J., Yang, F., Yang, D.Q., Jiang, P., Liu, R.D., Zhang, X., Cui, J. \& Wang, Z.Q. (2018). Molecular characterization of Trichinella spiralis galectin and its participation in larval invasion of host's intestinal epithelial cells. Veterinary Research 49: 79. https://doi.org/10.1186/s13567-018-0573-3

Xu, J., Xu, Y.X.Y., Yue, W.W., Hao, H.N., Liu, R.D., Long, S.R., Wang, Z.Q. \& Cui, J. (2021a). Specific binding of aspartic protease and enterocytes promotes Trichinella spiralis invasoin of murine intestinal epithelium cells. Tropical Biomedicine 38: 160-171. https://doi.org/10.47665/tb.38.1.028 
Xu, J., Yue, W.W., Xu, Y.X.Y., Hao, H.N., Liu, R.D., Long, S.R., Wang, Z.Q. \& Cui, J. (2021b). Molecular characterization of a novel aspartyl protease-1 from Trichinella spiralis. Research in Veterinary Science 134: 1-11. https://doi.org/10.1016/ j.rvsc.2020.11.008

Yan, S.W., Hu, Y.Y., Song, Y.Y., Ren, H.N., Shen, J.M., Liu, R.D., Long, S.R., Jiang, P., Cui, J. \& Wang, Z.Q. (2021). Characterization of a Trichinella spiralis cathepsin $X$ and its promotion for the larval invasion of mouse intestinal epithelial cells. Veterinary Parasitology 297: 109160. https:/ /doi.org/10.1016/j.vetpar.2020.109160

Yang, D.Q., Zeng, J., Sun, X.Y., Yue, X., Hu, C.X., Jiang, P., Liu, R.D., Cui, J. \& Wang, Z.Q. (2020a). Trichinella spiralis: RNAimediated silencing of serine protease results in reduction of intrusion, development and fecundity. Tropical Biomedicine 37: 932-946. https://doi.org/10.47665/ tb.37.4.932

Yang, F., Guo, K.X., Yang, D.Q., Liu, R.D., Long, S.R., Zhang, X., Jiang, P., Cui. J. \& Wang, Z.Q. (2020b). Functional analysis of Trichinella spiralis serine protease 1.2 by siRNA mediated RNA interference. Tropical Biomedicine 37: 458-470.

Yang, F., Yang, D.Q., Song, Y.Y., Guo, K.X., Li, Y.L., Long, S.R., Jiang, P., Cui, J. \& Wang, Z.Q. (2019). In vitro silencing of a serine protease inhibitor suppresses Trichinella spiralis invasion, development, and fecundity. Parasitology Research 118: 2247-2255. https://doi.org/10.1007/s00436-019-06344-4

Yang, W., Li, L.G., Liu, R.D., Sun, G.G., Liu, C.Y., Zhang, S.B., Jiang, P., Zhang, X., Ren, H.J., Wang, Z.Q. et al. (2015). Molecular identification and characterization of Trichinella spiralis proteasome subunit beta type-7. Parasites \& Vectors 8: 18. https://doi.org/10.1186/s13071-014-0626-z

Yue, X., Sun, X.Y., Liu, F., Hu, C.X., Bai, Y., Yang, D.Q., Liu, R.D., Zhang, X., Cui, J. \& Wang, Z.Q. (2020). Molecular characterization of a Trichinella spiralis serine proteinase. Veterinary Research 51: 125. https://doi.org/10.1186/s13567020-00847-0
Zarlenga, D., Thompson, P. \& Pozio, E. (2020). Trichinella species and genotypes. Research in Veterinary Science 133: 289-296. https://doi.org/10.1016/j.rvsc.2020.08.012

Zhang, N., Li, W. \& Fu, B. (2018). Vaccines against Trichinella spiralis: Progress, challenges and future prospects. Transboundary and Emerging Diseases 65: 1447-1458. https:/ /doi.org/10.1111/tbed.12917

Zhang, S.B., Jiang, P., Wang, Z.Q., Long, S.R., Liu, R.D., Zhang, X., Yang, W., Ren, H.J. \& Cui, J. (2016). DsRNA-mediated silencing of Nudix hydrolase in Trichinella spiralis inhibits the larval invasion and survival in mice. Experimental Parasitology 162: 35-42. https://doi.org/10.1016/j.exppara. 2016.01.005

Zhang, X.Z., Sun, X.Y., Bai, Y., Song, Y.Y., Hu, C.X., Li, X., Cui, J. \& Wang, Z.Q. (2020a). Protective immunity in mice vaccinated with a novel elastase-1 significantly decreases Trichinella spiralis fecundity and infection. Veterinary Research 51: 43. https://doi.org/10.1186/s13567-020-00767-z

Zhang, Y., Zeng, J., Song, Y.Y., Long, S.R., Liu, R.D., Jiang, P., Zhang, X., Cui, J. \& Wang, Z.Q. (2020b). Vaccination of mice with a novel trypsin from Trichinella spiralis elicits the immune protection against larval challenge. Vaccines 8: 437. https://doi.org/10.3390/vaccines 8030437

Zhang, Y.L., Wang, Z.Q., Li, L.G. \& Cui, J. (2013). Molecular characterization of Trichinella spiralis aminopeptidase and its potential as a novel vaccine candidate antigen against trichinellosis in BALB/c mice. Parasites \& Vectors 6: 246. https://doi.org/10.1186/1756-3305-6-246

Zheng, J., Cheng, Z., Jia, H. \& Zheng, Y. (2016). Characterization of aspartyl aminopeptidase from Toxoplasma gondii. Scientific Reports 6: 34448. https://doi.org/10.1038/srep34448 